\title{
Copy and Paste Lawmaking: Legislative Professionalism and Policy Reinvention in the States
}

\author{
Eric Hansen \\ Loyola University Chicago, ehansen4@luc.edu \\ Joshua M. Jansa \\ Oklahoma State University \\ Virginia Gray \\ University of North Carolina at Chapel Hill
}

Follow this and additional works at: https://ecommons.luc.edu/politicalscience_facpubs

Part of the Political Science Commons

Author Manuscript

This is a pre-publication author manuscript of the final, published article.

\section{Recommended Citation}

Hansen, Eric; Jansa, Joshua M.; and Gray, Virginia. Copy and Paste Lawmaking: Legislative Professionalism and Policy Reinvention in the States. American Politics Research, 47, 4: 739-767, 2018. Retrieved from Loyola eCommons, Political Science: Faculty Publications and Other Works, http://dx.doi.org/10.1177/1532673X18776628

This Article is brought to you for free and open access by the Faculty Publications and Other Works by Department at Loyola eCommons. It has been accepted for inclusion in Political Science: Faculty Publications and Other Works by an authorized administrator of Loyola eCommons. For more information, please contact ecommons@luc.edu. \section{(c) $($ () $\ominus$}

This work is licensed under a Creative Commons Attribution-Noncommercial-No Derivative Works 3.0 License. (c) Sage Publishing, 2018. 


\title{
Copy and Paste Lawmaking: Legislative Professionalism and Policy Reinvention in the States
}

\author{
Joshua M. Jansa \\ joshua.jansa@okstate.edu \\ Department of Political Science \\ Oklahoma State University
}

\author{
Eric R. Hansen \\ ehansen4@luc.edu \\ Department of Political Science \\ Loyola University Chicago
}

\author{
Virginia Gray \\ vagray@email.unc.edu \\ Department of Political Science \\ University of North Carolina at Chapel Hill
}

April 12, 2018 


\begin{abstract}
Research on policy reinvention tends to focus on whether policies become more or less comprehensive over time while neglecting to explain copying policy language verbatim. We argue that the extent to which lawmakers reinvent policy depends on the resources available to them. Lawmakers serving in more professional state legislatures have greater capacity to reinvent policies. In contrast, lawmakers serving in less professional settings are more likely to copy policy language. As evidence, we gather bill texts of 12 policies that diffused across the 50 states between 1982 and 2014. Using cosine similarity scores to measure language copying, we find that less professional legislatures copy more text from previous adopters, and that the likeliest culprit is a lack of funding for staff assistance. The findings have implications for states' ability to amend policies to suit their own citizens' needs.
\end{abstract}

Keywords: policy reinvention, legislative professionalism, text analysis, state politics 
As policy ideas diffuse from one state to others, lawmakers tend to adjust the content of the policy to fit the political and economic circumstances of their own states (Boehmke 2009; Carley, Nicholson-Crotty, \& Miller 2016; Clark 1985; Glick \& Hays 1991; Hays 1996; Karch 2007; Mooney \& Lee 1995; Taylor, Lewis, Jacobsmeier, \& DiSarro 2012). Political scientists have traditionally viewed reinvention as a process of social learning through which later adopting states make adjustments that are increasingly comprehensive and converge upon an optimal policy (Glick \& Hays 1991; Mooney \& Lee 1995). However, researchers have noted that as some states reinvent policy ideas, others simply adopt policies with language copied and pasted from previous adopters' bills (Hertel-Fernandez 2014; Hertel-Fernandez \& Kashin 2015; Kroeger 2015). Why do some states reinvent policy while others copy it verbatim?

In this study, we are interested in exploring how legislative institutions create incentives for lawmakers to copy language from other states and, consequently, disincentivize policy reinvention. We argue that states with less professional legislatures will be more likely to copy language from previous adopters. Features of professional legislatures, like extended time in session and greater staff assistance, give lawmakers greater opportunity to identify social problems and consider policy solutions, including those advanced in other states. Lawmakers facing similar policy problems in less professional legislatures have a reduced capacity to reinvent policy, and are more likely to borrow policy solutions with few changes from other states.

For evidence, we turn to the texts of nearly 400 bills for 12 policies that diffused across the states between 1982 and 2014. We calculate cosine similarity scores, a method used to detect plagiarism, to determine the amount of copied text in passed versions of state legislative bills. Analyzing the data using a Heckman selection model to distinguish factors that lead to bill adoption and text copying, we find strong support for our hypothesis that less professional legislatures copy more text from previous adopters. The results suggest that a lack of resources for legislative staff could be responsible for that relationship, though the findings on this point are not conclusive.

This study contributes a new strategy for measuring policy reinvention, adding to a growing body of research that uses text analysis methods to study and understand how and why policies diffuse across states (Garrett \& Jansa 2015; Hertel-Fernandez \& Kashin 2015; Kroeger 2015). 
It also provides evidence that better-resourced state legislatures tend to be more innovative because they have greater staff resources. Although it is popular to slash legislative staff budgets, or let them stagnate, doing so can curb the legislature's ability to innovate in policy and to address emerging social problems.

\section{Legislative Professionalism and Reinvention}

As policies diffuse across states, lawmakers borrow not only ideas but also exact language from legislation in other states. In some cases, this practice saves lawmakers the time and effort of crafting new policy language when model text already exists. Borrowing exact language at best indicates that lawmakers have consciously decided that the bill text from another state will suit their own political needs and their state's policy needs. At worst, however, borrowing exact language might indicate thoughtless adherence to a political stance, lazy lawmaking, or even ignorance of the exact implications of a bill's content for one's own state.

For example, Indiana's controversial Religious Freedom Restoration Act (RFRA) included borrowed provisions defining corporations as people, and that religious freedom could be used as a defense in cases not involving the government. ${ }^{1}$ Soon after passage, it became apparent that the borrowed provisions, when combined into a single bill, provided enough leeway for businesses to legally discriminate against LGBT citizens. Lawmakers quickly passed an amendment that clarified the legal language. ${ }^{2}$ In another instance, Governor Jay Nixon of Missouri vetoed a bill because it referenced the wrong federal statute. ${ }^{3}$ This significant error had been copied and pasted by Missouri lawmakers from an American Legislative Exchange Council (ALEC) model bill.

Copying language also has potential unintended consequences in states where the demographic or regulatory context differs from earlier adopters. When it comes to demographics, the target populations intended to benefit from a policy vary in character across states. A one-size-fits-all approach to policy might not serve the interests of the target population in a copying state in the same way it did in the innovating state. When it comes to implementation, existing laws and organizational structures may interfere with the execution of new policies 
written with language tailored for other contexts. Since states tend to borrow language from one another, and may do so with haste and without regard for errors, it is important to know what leads to more or less text borrowing overall. Understanding why state lawmakers borrow legislative language whole cloth, rather than adapting policy ideas to fit the specific needs of their constituents, can help scholars and practitioners improve policymaking and governance at the state level.

We expect that institutional resources affect lawmakers' likelihood of copying policy language by altering the time and information available to them as they assess the strengths and shortcomings of new policy ideas. Professional legislatures tend to provide greater institutional resources, including higher funding and longer sessions that allow lawmakers and their staffs to spend time and attention on policy, than citizen legislatures (Squire 1992). Greater institutional resources allow lawmakers and their staffs the ability to receive more policy-relevant information from a variety of sources (whether newspapers, lobbyists, colleagues, or national organizations) and, crucially, to act on that information during the legislative session. Therefore, states with more professional legislatures will be more likely to reinvent policy to suit their particular needs and goals.

Although the policy reinvention literature explores why states amend and adapt policy ideas borrowed from their peers (Carley et al. 2016; Clark 1985; Glick \& Hays 1991; Hays 1996; Karch 2007; Mooney \& Lee 1995; Taylor et al. 2012), researchers have not rigorously tested the role of resources. The major question arising from the reinvention literature is, to what extent does learning over time affect the contents of diffusing policies? Glick and Hays (1991) and Mooney and Lee (1995) argue that policies become increasingly comprehensive over time as lawmakers learn and add on their own changes to the innovations of early adopters. In contrast, Clark (1985) suggests that later adopting states will be unlikely to shift the status quo quite so far as innovating states, resulting in less comprehensive policies over time. In both cases, research aims to predict the general direction that policy reinvention will move. However, it does not try to explain the variation in states' decisions to reinvent or copy policy as it diffuses.

Research on the factors that explain this variation is scant. Hays (1996) provides evidence that states with greater social need for a policy tend to adopt less comprehensive policies than 
innovating states. However, the study finds inconclusive evidence on the role of professionalism and ideological differences between states. ${ }^{4}$ More recently, Carley et al. (2016) point out that factors internal to a state, such as party politics, administrative institutions, and economic considerations, also bear on the decision to reinvent a policy.

The broader literature on policy diffusion — which tends to focus on the spread of policy ideas rather than contents of policy itself - often suggests that resources are important to states' ability to innovate. With more available resources, legislators can engage in serious discussions of policy with staff, colleagues, and stakeholders. Longer session lengths and larger staff budgets give bill sponsors more time and assistance to research and craft novel policies while reserving adequate time for constituent service, public appearances, and fundraising. Even for nonsponsors, more time and resources gives lawmakers greater opportunity to vet their colleagues' proposals and offer amendments. As a result, professional legislatures innovate more in policy and rely less on peer states for policy ideas. This explanation is supported by the correlation between state policy innovativeness and professionalism (or its correlate, available fiscal resources) present across multiple studies (Clark \& French 1984; Desmarais, Harden, \& Boehmke 2015; Gray 1973; Ka \& Teske 2002; Walker 1969).

Though scholars generally agree that resources allow for greater innovation, the evidence supporting that conclusion is surprisingly mixed. Many studies omit a variable for resources or professionalism from their models altogether (Balla 2001; W. D. Berry \& Baybeck 2005; Boehmke \& Witmer 2004; Mooney 2001; Volden 2006), while others find a null or even negative relationship between professionalism and innovation (Boehmke \& Skinner 2012; Boushey 2010; Desmarais et al. 2015; Haider-Markel 2001; Karch, Nicholson-Crotty, Woods, \& Bowman. 2016). Few have articulated hypotheses in contrast with the conventional wisdom in the field. It could be the case, for example, that resources play no systematic role in enabling states to innovate or reinvent policy; rather, professionalized state legislatures both innovate and borrow at the same frequency as their peer legislatures. Another possibility is that professional legislatures may also have greater capacity to monitor policy implementation and revise policy down the road if needed, making it less costly to copy and paste from other states. More professional governments often become earlier adopters of diffusing policies (e.g. Shipan \& Volden 2006, 2008, 2014), 
suggesting a tendency to borrow and borrow quickly. Though these alternative relationships remain in the realm of possibility, we expect that the greater resources for policymaking that professional legislatures offer should create more opportunity for changes to bill text.

Professionalism Hypothesis: As legislative professionalism increases, policy language in approved bills will be less similar to the policy language approved in previously adopting states.

\section{Staff Expenditures, Session Length, and Salary}

Professionalism is typically conceptualized as being marked by three components: session length, staff expenditures, and the salaries paid to lawmakers (Squire 1992). Bowen and Greene (2014) warn that researchers studying professionalism should think carefully about whether these components individually contribute to the outcome of interest (see also Carnes \& Hansen 2016; Kousser \& Phillips 2009). Though we expect that more professional legislatures on balance will copy less language, we do not expect all three components to affect reinvention.

One facet of professionalism likely to have a substantial effect on language borrowing is staff expenditures. Legislatures with more funding for research centers, committee personnel, and personal legislative aides likely have a greater capacity to research, innovate, and reinvent policy solutions for their jurisdictions. Further, those legislatures will be more able to hire professionally trained individuals, compensate them well, and give them the resources to succeed. Legislatures with small, cash-strapped, amateur staffs may have to rely more on the work of previous adopters as beginning templates for their work. In sum, states that dedicate fewer resources to legislative staff will be more likely to borrow from other states. We state this hypothesis formally below.

Expenditures Hypothesis: As legislative staff expenditures increase, policy language in approved bills will be less similar to the policy language approved in previously adopting states.

Another important component of professionalism is session length. Lawmaking is an arduous, time-consuming process. Despite the time demands, legislators must also devote significant 
time to politics, including running for reelection, interacting with constituents, fundraising, and building support for policy proposals within their chamber. Needing to accomplish both policy and political goals in a time-constrained environment, legislators and their staff may decide to copy policy language from existing sources rather than writing policies anew. The more timeconstrained a legislator is, the more likely he or she is to look for these shortcuts to solving social problems.

Session length varies across states. Some states give legislators a few months every two years to deliberate on policy; other states meet year-round. States that have longer sessions give their legislators the time needed to draft, debate, revise, and consider more innovative proposals before adjournment. Though legislators spend time thinking about and drafting policy outside of session, the legislature collectively spends less time deliberating and amending policies proposed by members when facing short bill passage deadlines before required adjournments. We expect states with longer sessions will be less likely to borrow language from other states. We state this hypothesis formally below.

Session Hypothesis: As legislative session length increases, policy language in approved bills will be less similar to the policy language approved in previously adopting states.

The final component of professionalism is the salary paid to lawmakers. Unlike the other two components, we have little reason to expect that what lawmakers are paid corresponds to legislatures' likelihood to reinvent policy.

Legislators are paid the same at the end of the year regardless of the number of bills they introduce and pass, meaning there are no monetary incentives for them to copy and paste bills verbatim from other states. There are also no salary-based incentives to spend time crafting a policy reinvented from another jurisdiction. If there were any reason to suspect that salary matters, it would be that greater salary allows for greater policy expertise among legislators, perhaps by attracting more skilled professionals to run for office (Carnes \& Hansen 2016). However, professional skills and training do not guarantee policy expertise across issue areas. Furthermore, we cannot point to any evidence that shows that legislators with professional backgrounds write more original or better quality policy bills than legislators without profes- 
sional backgrounds. In short, we expect salary to have no bearing on language borrowing in states.

Salary Hypothesis: As legislative salary increases, policy language in approved bills will be neither more nor less similar to the policy language approved in previously adopting states.

\section{Research Design and Data}

To test our hypotheses, we measured the similarities in language in twelve policies that diffused across multiple states. Table 1 displays the selected policies, as well as the time periods of diffusion, descriptions of each policy, and which (if any) interest groups propagated model legislation for the policy. ${ }^{5}$

We do not claim these policies to be representative of all state policies. The universe of state policies is unknown, making it difficult to assess how representative this set of policies is to all other policies. Researchers simply do not know the sampling frame from which to pull a random sample of state policies, and thereby ensure a representative sample. This is not a new problem in the study of policy diffusion and reinvention. Policy diffusion research in general suffers from a "pro-innovation" bias in that nearly all studies examine a single policy that successfully diffused (Karch et al. 2016) which is almost certainly unrepresentative of state level policies. We can claim, however, that our sample is reasonably well-balanced on a number of factors, giving us essentially a quota sample of state policies.

We selected policies that varied on key factors, including whether the policy addressed an economic or social issue; whether the policy was backed by an interest group's model legislation; the rate of diffusion; how many states the policy diffused to; and the ideological direction of the policy. ${ }^{6}$ An additional strength of our research design is its scope. By analyzing twelve policies, our study also provides a substantially larger scope than previous studies of policy reinvention (e.g. Hays 1996) and most diffusion studies, with some exceptions (Boehmke \& Skinner 2012; Desmarais et al. 2015; Karch et al. 2016), thus yielding much more generalizability than most studies. 
[Table 1 about here.]

For each policy, we gathered observations in state-years, similar to an event history analysis (EHA) data framework. Observations were recorded for all states beginning in the year that the first state adopted a given policy and proceeding until the year that the most recent state adopted or 2014, whichever occurred first. When a state selected into adopting a policy, the state was removed from future year observations (as in an event history data set). Observing the full range of state-years for all 12 policies yielded more than 5700 observations of policystate-years.

However, our observations of language diffusion are censored based on whether the state adopted a policy. In order to model the diffusion of policy language, we turn to a Heckman selection model (Heckman 1979). We assume language borrowing occurs as a two-stage process. In the first stage, state legislatures select into adopting another state's policy idea due to learning, competition, or emulation. In the second stage, legislatures decide how much language to borrow from the previous state. This follows an interpretation that states adopt diffusing policies based primarily on lawmakers' impressions of the content, with less regard for the specific content of the policy itself. In this interpretation, policy adoption occurs because a majority of lawmakers support the policy idea. The particular policy language would emerge as a product of the legislative process that transmits ideas into laws.

Such a two-stage process has been theorized in previous work, though not explicitly modeled. Karch (2007) argues that the decision to adopt is separate from decisions about policy content, or what the bill actually says. Carley et al. (2016) also demonstrate that differing factors account for the decision to adopt than for the decision to reinvent policy. Though they adopt a dyadic modelling approach, they write that, "It is not merely plausible but logically necessary that these [adoption and reinvention decisions] are in fact distinct sequential decisions, as lawmakers first decide that they want a general class of policy, then decide what the specific characteristics of that policy should be" (23).

An additional reason to support this modelling assumption is that many collective decisions in state legislatures are based on pressures besides the language of a bill, such as party (e.g. 
Lee 2009) or constituency pressures (e.g. Fenno 1978), or external pressure from the federal government (Gray 1973). Ideally, legislators would decide to vote for or against a given bill based in large part on the language of the bill itself. However, it is quite reasonable to assume that on many bills, most legislators who support or oppose the general idea of a bill will not be swayed from their original stance by changes to the wording. Partisan lawmakers might also vote for a bill that party leadership approves, regardless of the specific content.

Of course, there are exceptions. Often a bill can be passed or defeated by changes to the wording that move a small number of legislators between "yea" and "nay." Even if a lawmaker disagrees with some parts of a bill, their disagreement with the wording will likely neither change their ultimate support for or opposition to a bill, nor motivate them enough to introduce an amendment - especially under pressure from other political actors. It is important to model both the decision to adopt and the similarity of the policy to previous adoptions, as the Heckman model allows.

\section{Stage 1: Policy Adoption}

In the first stage, we model a state's decision to select into adopting a given policy. The dependent variable in the first stage is a binary indicator of whether the state adopted the policy in a given year. In this study, we are not so interested in explaining why states adopt certain policies or in distinguishing between mechanisms of diffusion as we are interested in explaining why states copy language. However, modeling the decision to adopt in the first stage is important to obtaining accurate estimates for the factors that influence text borrowing in the second stage. Thus, we include several explanatory variables that capture states' potential motivations for adopting a diffusing policy: competition, social learning, and emulation. According to a meta-analysis of the diffusion literature from Maggetti and Gilardi (2015), quantitative measures of these concepts are inconsistently applied and frequently overlap. We include several variables from the literature previously found to be associated with policy adoption, but make no claims about which specific mechanisms these variables represent.

We include a variable to measure whether bordering states have previously adopted the policy under observation. The variable Border is a binary variable, with values of 1 indicating 
that at least one bordering state has previously adopted the policy. Many scholars find it to be a good predictor of state policy adoption (Baybeck, Berry, \& Siegel 2011; Carley et al. 2016; Karch et al. 2016; Shipan \& Volden 2014), though others caution against relying solely upon a bordering states to measure or explain diffusion (Desmarais et al. 2015; Gilardi 2016; Volden, Ting, \& Carpenter 2008).

States often adopt policies that ideologically similar states have adopted (Grossback, NicholsonCrotty, \& Peterson 2004; Pacheco 2012), regardless of whether the previous state can provide evidence that the policy was successful in achieving social or economic goals (Volden et al. 2008). Therefore, we also include the variable Ideological Distance. This is calculated as the difference in government ideology between the observed state and the initial adopter on a policy, as measured using estimates from W. D. Berry, Ringquist, Fording, and Hanson (1998). We use the distance to the initial adopter because the first state sets the stage for the diffusion process and signals the ideological direction of a bill to all subsequently adopting stats. Using the same data source, we also include the variable Government Ideology in the observed state-year, with higher values indicating more liberal governments.

Wealthier states may be more likely to adopt new policy innovations because a larger base of revenue ensures that more funds will be available for policy implementation (F. S. Berry \& Berry 1990; Boehmke 2009). We measure state wealth using state Per Capita Income in $\$ 10,000$ s. Data come from the federal Bureau of Economic Analysis. Estimates are adjusted for inflation.

Interest groups and interstate organizations sometimes propagate model legislation, which reduces the costs of policy drafting for potential bill sponsors (Garrett \& Jansa 2015; HertelFernandez 2014). The existence of model legislation also indicates a broad effort by these organizations to lobby multiple state legislatures to adopt their preferred policies. We include Model Legislation as an indicator variable, with values of 1 marking the existence of model legislation for the policy in question. Political organizations created such texts for six of our 12 policies. ${ }^{7}$

Finally, the temporal rate of diffusion varies across policies (Boushey 2010). We include variables for time and its squared value, to account for overall time passed and over-time 
changes in the rate of diffusion. Time is measured as a count of the years passed between the observed state-year and the year of the innovating state's adoption.

\section{Stage 2: Language Similarity}

In the second stage, we measure reinvention by estimating how much language an adopting state borrowed from a previously adopting state using computerized text analysis. Previous research has measured reinvention by coding provisions of diffusing policy and counting how many of the provisions appeared in the policies of both earlier and later adopters (Boehmke 2009; Glick \& Hays 1991; Hays 1996; Mooney \& Lee 1995; Taylor et al. 2012). However, coding schemes have the potential to focus attention on certain salient sections of a policy and ignore intricacies of language. Our approach captures reinvention by comparing all policy language in one bill to all policy language in another bill and removing human interpretation of the content from the measurement process.

\section{Dependent Variable}

Our dependent variable is a continuous measure of the similarity of the text to the most similar previous text. We gathered the bill texts from all states that adopted a given policy. ${ }^{8}$ Once the bill texts were collected, they needed to be prepared in order to facilitate comparison. ${ }^{9}$ Then, we calculated a similarity score between each pair of state bills. ${ }^{10}$

The method of comparison we used is cosine similarity, a common plagiarism detection technique that has previously been used to analyze the similarity of bills in the study of diffusion (Garrett \& Jansa 2015). The cosine method produces a vector of word frequencies in one text and compares it to the vector of word frequencies from another text. It does this by taking the product of the two vectors divided by the matrix norm of the two vectors. The result is a similarity score that can range from 0 to 1 . The calculation of a cosine similarity between two hypothetical word frequency vectors, A and B, is shown in Equation 1.

$$
\operatorname{Cos} \operatorname{Sim}(A, B)=\frac{A * B}{\|A\| *\|B\|}=\sum_{i=1}^{n} \frac{A_{i} * B_{i}}{\sqrt{\sum_{i=1}^{n}\left(A_{i}\right)^{2}} * \sqrt{\sum_{i=1}^{n}\left(B_{i}\right)^{2}}}
$$


The scores themselves are similar to Pearson correlations except that they change with shifts in the scale of $\mathrm{A}$ or B. ${ }^{11}$ We think it is most useful to consider the similarity scores as a relative measure of how similar the two texts are, with the score of 1 indicating identical texts (in terms of the frequency of words used), and the score of 0 indicating no similarity. ${ }^{12}$

Cosine similarity is sometimes referred to as a "bag of words" approach in that it compares texts using counts of word frequencies rather than strings of words. Scholars have found that cosine similarity achieves a medium to high plagiarism detection rate, especially in instances of copy-and-paste plagiarism (Potthast, Stein, Eiselt, Barron-Cedeno, \& Rosso 2011). Since we are examining the degree of similarity between state adoptions of defined policies, the relative similarity measure produced by the cosine method is ideal for our application.

With all the bills compared, we set out to construct our dependent variable Similarity Score. To do this, we calculated the similarity score for each dyad formed by the observed state and all previously adopting states. ${ }^{13}$ Then we identified the largest similarity score, assuming it represented the greatest possible amount of emulation of a previously adopting state's language and assigned it as the dependent variable for the observed state. In doing so, we depart from previous research that uses observations of all possible state dyads to infer diffusion networks (Desmarais et al. 2015; Volden 2006). However, using all possible dyads might provide evidence of copying where no copying occurred, especially since our method will report some similarity in word use in every dyad due solely to the fact that these diffusing policy bills discuss similar topics. By measuring each observation of bill adoption using the most likely instance of copying, we reduce the likelihood of obtaining spurious results. ${ }^{14}$ We transformed the dependent variable from 0 to 1 scores to a 0 to 100 scale for simpler presentation of results in subsequent tables.

[Figure 1 about here.]

Figure 1 provides an illustration of how the measure works. The figure shows a portion of the 1999 Texas safe haven law compared to the 2000 Indiana safe haven law. The similarity score between the two bills is 71.2 , which is a relatively high degree of similarity overall and on safe haven laws in particular. ${ }^{15}$ While there is clearly language copied directly from Texas' law, Indiana's law provides a lower age requirement for taking infants into custody and includes 
language protecting the identity of the individual who left the infant. We will revisit this example in the results section of the paper.

\section{Independent Variables}

To test the professionalism hypothesis, that more professional state legislatures borrow less language from previously adopting states, we turn to the updated index of Professionalism calculated by Squire (2007) for the year 2003. The Squire index measures staff resources, session length, and salary as a comprehensive measure of professionalism. The Squire index values vary across states, but produce only one value per state over time. ${ }^{16}$ To account for potential year to year variation in professionalism, we also employ Bowen and Greene's (2014) professionalism index. Their index is measured for each state biennially, by taking the first dimension in the multidimensional scale of staff expenditures, session length, and salary. However, Bowen and Greene's measure contains missing values across state-years. Given the shortcomings of each index, we report the results using both measures.

Bowen and Greene (2014) also provide data on each component part of professionalism, which we used to test our associated hypotheses. Staff Expenditures are per-legislator staff funding, not including legislative salaries, in hundreds of thousands of constant 2010 dollars. Session Length is the number of days the legislature met in the two-year period. Salary is measured as legislators' base pay in thousands of constant 2010 dollars. We consider these variables both individually and jointly in the models below.

We include four control variables in the second stage of the model to capture factors that might also lead states to copy more language from previous adopters. States may be more likely to see policy language converge over time as learning occurs and later adopting states arrive at a consensus that a certain type of language is necessary to achieve a desired effect of policy (Clark 1985; Glick \& Hays 1991). We include two variables to capture temporal convergence. The first is Time, which as in the first stage of the model is the count of years between the observed state-year and the year of the innovating state's initial adoption. The second is Order, which is simply the order, one through fifty, in which the states adopted the policy over time. States that adopt a policy in the same year are assigned the same value for this variable. We 
include the order variable in addition to the time variable to account for the fact that policies diffuse at varying rates (Boushey 2010). The variables positively correlate only moderately at $r=0.30$.

The third variable we include is an indicator for Model Legislation, also included in the first stage and described above. Again, model legislation is specifically written to reduce costs of time and effort on the part of bill sponsors. The propagation of model legislation, if successful, should lead to more similarly worded policies emerging from state legislatures, as legislators are more likely to be working off a common model when drafting their legislation if there is interest group sponsored model legislation on the issue.

The fourth variable we include is an indicator for Term Limits. Term limits put constraints on lawmakers' ability to innovate on policy by giving them less time to develop deep policy expertise and relationships with their fellow lawmakers (see Carey, Niemi, Powell, \& Moncrief 2006; Kousser 2005). This may constrain legislators' ability to craft original policy language in their own office or with colleagues. Supporting this idea, Garrett and Jansa (2015) find that states with term-limited legislators were more likely to borrow language on diffusing policies. Values of 1 for this variable indicate that a state has term limits imposed for the observed year. ${ }^{17}$

\section{Results}

Table 2 presents the results of the Heckman selection model. ${ }^{18}$ The upper panel of the table presents coefficient estimates for variables predicting state selection into policy adoption, while the lower panel presents estimates for variables predicting language copying. Robust clustered standard errors, clustered by state, are presented in parentheses. ${ }^{19}$ Model 1 presents the estimates for the model using the Squire index. Model 2 presents the estimates for the model using the Bowen and Greene index. Both of these models test the professionalism hypothesis. Models 3 through 5 test the expenditures, session length, and salary hypotheses in that order. We estimated an additional Model 6 as a placebo test to assess whether results in Models 3, 4 and 5 were being driven by the unmodeled endogenous relationship between professionalism 
components.

An assumption of a Heckman selection model is that the data are distributed bivariate normal. The results of a Doornik-Hansen test of multivariate normality showed that our data violated the distributional assumptions of the Heckman model. We replicated the results from Table 2 using a robust sample selection model developed by Zhelonkin, Genton, and Ronchetti (2016). The robust model is a semiparametric model that relaxes the distributional assumptions of a Heckman selection model and produces consistent estimates when those assumptions are not met. The full results of the robust model appear in Table 4 in the appendix. The robust results largely mirror the results presented in Table 2, though we note in the text below when the findings from the two models diverge.

[Table 2 about here.]

\section{Stage 1 Results}

Before turning to a test of our hypotheses in the second stage of the model, we describe the results in the first stage. The dependent variable is a binary measure of whether a state adopted a given policy in a given year. The results fall largely in line with previous results from the diffusion literature. A negative coefficient estimate for the ideological distance variable indicates that as the distance between the innovating and observed state increases, the observed state becomes decreasingly likely to adopt the policy. The coefficient estimates for the model legislation, bordering states, and income variables are positively signed and statistically significant. Respectively, these results indicate that states are more likely to adopt policies with interest group model legislation behind it; that states are more likely to adopt when a neighboring state has already adopted the policy; and that wealthier states are more likely to adopt diffusing policies (though the estimate for this coefficient fails to reach statistical significance in Model 2). The government ideology variable is negatively signed. ${ }^{20}$ Taken at face value, this finding might suggest that more conservative governments are more likely to adopt diffusing policy innovations than liberal states, all else equal. However, we limit our interpretation of this finding to mean that more conservative governments were more likely than liberal governments 
to adopt the 12 policies in our sample. A more definitive conclusion about whether liberal or conservative governments are more likely to adopt diffusing policy innovations overall would require a more representative sample of all policies considered at the state level than those in our current sample. The models produce null results for the time variables.

Overall, the results from the first stage accord with predictions from previous studies of policy diffusion. The results were also consistent across all models. Further, the inverse Mills ratio was statistically significant in all models (see Table 2). The inverse Mills ratio measures the correlation between the errors in Stage 1 and Stage 2; if significant it demonstrates that there is indeed selection bias and the use of the Heckman model is justified to model the selection process.

\section{Stage 2 Results}

We turn to interpreting the second stage of the model, which seeks to explain the extent to which states borrow language from previous states, given that they have selected into adopting a given policy. The dependent variable is Similarity Score, which is the cosine similarity score between the text of the adopting state's policy and the most similar text from a previously adopting state.

The professionalism hypothesis states that as legislative professionalism increases, policy language in approved bills will become less similar to the policy language approved in previously adopting states. If this is true, we should expect to see a negative and statistically significant coefficient estimate for the professionalism variable in the second stage of Models 1 and 2 .

Turning to the results in the lower panel of Table 2, this is indeed what we find in Model 1. An increase in legislative professionalism is associated with reduced similarity scores. In substantive terms, the coefficient estimate indicates that a one-unit increase in the index (roughly the difference between an average state legislature like Iowa's and a fairly professional legislature like Illinois' on Squire's measure) translates to bills with an average decrease of 3.49 in the similarity score. Moving from the least professional legislature (New Hampshire, Squire index $=0.27$ ) to the most professional (California, Squire index $=6.26)$, Model 1 predicts that a bill would have a similarity score 20.7 lower in comparison to previous adopters in California than 
it would in New Hampshire. On a 0 to 100 scale, this represents a substantively large reduction in language borrowing as professionalism increases.

Using Bowen and Greene's index as an alternate measure, we find a similar negative and statistically significant relationship in Model $2 .{ }^{21}$ Use of this time-dynamic index indicates a decrease of 2.33 in the similarity score for a one-unit increase in the index. The difference in predicted cosine similarity scores between California and New Hampshire is 13.96 - a smaller difference than predicted using Squire's index, but substantively large nonetheless. The results from both Model 1 and 2 support the professionalism hypothesis.

We turn next to testing the hypotheses for the component variables of professionalism. First, the expenditures hypothesis holds that states that spend more on staff will borrow less language from previously adopting states. If this is true, we should see a negative and statistically significant coefficient estimate for the Staff Expenditures variable in Model 3. We find supporting evidence based on the estimates. Increasing staff expenditures per legislator by $\$ 100,000$, which is about the difference between an average state legislature like Arizona and a fairly professional legislature like Oregon, translates to an average decrease in a cosine similarity score of 4.8, controlling for the other variables. Moving from the lowest per legislator expenditure in 2010 (New Hampshire, $\$ 70,000$ per legislator) to the highest (California, $\$ 5,523,000$ per legislator), yields an average decrease in the cosine similarity score of 26.2 -more than a quarter of the range of the 0-100 scores.

Next, the session hypothesis holds that states that allow their legislatures to meet for more days will borrow less language from previously adopting states. Like the expenditures hypothesis, if this is true, we should see a negative and statistically significant coefficient estimate for Session Length in Model 4. The results show that the longer a state legislature is in session, the less language the legislature copies and pastes from other states. Based on the coefficient estimate in Model 4, we calculate that increasing session lengths by 30 days per biennium leads to a small average decrease of 0.9 in the cosine similarity score. The difference between a rarely meeting legislature, like Wyoming (40 days in 2009-2010), and a legislature with no meeting limits, like New York (458 days in 2009-2010), is a decrease of 12.5 in cosine similarity score on average. 
Finally, the salary hypothesis holds that the salary paid to legislators should have no relationship with the amount of language borrowing. If this is true, the coefficient estimate for the Salary variable in Model 5 should not be statistically different from zero. In contrast with our expectation, we find that the coefficient estimate for the salary variable is negative and statistically significant. Our calculations show that a $\$ 10,000$ increase in legislative salary is associated with a decrease in cosine similarity score of 0.7 , on average. The difference between the best-paid legislature in 2010 (California, salary of $\$ 213,000$ ) and the worst-paid (New Mexico, $\$ 0$ ) results in a decrease of 14.91 in the average cosine similarity score. ${ }^{22}$

Given the unexpected results in Model 5, we conducted a placebo test to determine whether the statistically significant relationship between salary and text copying was being driven by the correlation between salary and staff expenditures. Model 6 reports the results of this placebo test, as we ran the model including all three component variables jointly. Among the three component variables in Model 6, only the estimate for staff expenditures is negative and statistically significant. Once all components are taken into account in the same model, neither a longer session length nor a higher salary appears to be associated with decreased language borrowing. Moreover, the negative relationship between staff expenditures and language borrowing is substantively large. Increasing staff expenditures per legislator by $\$ 100,000$ results in an average decrease in a cosine similarity score of 3.9, controlling for the other variables. In sum, Model 6 produces evidence in support of the expenditures hypotheses, robust to controlling for the other components of professionalism. However, we note that we do not obtain similar evidence from the robust sample selection model in Table 4. Though the size and sign of the coefficient estimate remain similar, the robust estimate is not statistically significant. The model provides no additional evidence in favor of the session hypothesis. It does provide evidence in support of our salary hypothesis, which predicted a null relationship between salary and policy language borrowing. ${ }^{23}$

The control variable estimates in the second stage of the model are consistent in size and significance across all model specifications. We find that the coefficient estimate for the term limits variable is signed in a positive direction, but the estimate is not statistically significant at the .05 level of confidence. The coefficient estimate for time is positive and statistically 
significant, indicating that copying policy language becomes more common as the years after the initial policy innovation increase. We also find a consistently positive and significant result for order of adoption. Together, these findings are consistent with a policy convergence interpretation of reinvention in which, after an early period of adjustment and experimentation, states settle on a common set of policy tenets over time.

We find a positive association between the presence of model legislation on an issue and language borrowing, statistically significant in all six models. In Model 1, the coefficient estimate suggests that when an external organization distributes model legislation on a policy, the cosine similarity score increases by roughly nine points on the 0-100 scale, controlling for the other variables. These findings suggest that organizations that promulgate model bills can leverage a good deal of influence over the contents of a policy adoptions.

Overall, the results show that greater legislative professionalism is associated with less copying. Of the models presented in Table 2, Model 2 (estimating Bowen and Greene's professionalism index alone) best fit the data based on BIC scores. The model fit statistics suggest that professionalism, rather than any individual component, is the best predictor of more original text. Among the component variables, staff expenditures appear to be the strongest predictor of more original text, given the findings in Model 6. However, we point to this finding as suggestive rather than conclusive; we are hesitant to draw the definitive conclusion that staff expenditures are the driving force due to the lack of significance for the coefficient estimate in the robust model.

\section{Interpreting the Estimated Effects on Similarity Score}

The cosine measure, while ideal for detecting copy and paste plagiarism between state bills, remains somewhat abstract. To provide context to the results from Table 2, we illustrate differences in pairs of bills that exist in the dataset. Recall Figure 1 above, which shows a portion of the Texas and Indiana safe haven laws. The similarity score between the two bills is 71.2 , or 28.8 less than an exact match. A difference of 28.8 mirrors the estimated effect size for staff expenditures when you move from the lowest to the highest state. The two bills exhibit similar language, and there is some evidence that Indiana used Texas' law as a starting 
template. However, Indiana's law provides looser language on the age requirement for taking infants into custody, saying that the infant must appear to be 30 days of age. The Indiana bill also includes language to protect the identity of the person who left the infant. Indiana reinvented key portions of the Texas bill, while still using very similar language overall. Our estimates suggest that states with large staff budgets have the capacity to customize policy to a similar degree, while states with smaller staff budgets will have more difficulty making important changes.

[Figure 2 about here.]

To illustrate the effect of session length, we provide Figure 2 which shows a portion of the 2005 Florida stand your ground law compared to Oklahoma's 2011 version. The cosine similarity between these two bills is 88.0, or about 12.0 less than an exact match. A difference of 12.0 is similar to the estimated effect size for session length. While these two bills are remarkably similar, Oklahoma expanded Florida's law by providing legal protection to those using deadly force for self-protection while at work. Substantively, this is an extremely important expansion of the policy, since it defines the boundaries of legal jeopardy for people using deadly force. Tying this pair of bills back to professionalism, our estimates suggest that states with long session lengths will be better able to reinvent policy than states with short sessions, even if that means copying most of the bill text from another state and including a few key changes, as Oklahoma did with Florida's stand your ground law.

\section{Results for Model Legislation Split-Sample}

Recall from Table 2 the effect of model legislation. Controlling for the usual causes of policy adoption, as well as the potential influences on borrowing language, model legislation stands out as a positive, significant, and consistent predictor of both adoption and language borrowing.

It could be argued, though, that model legislation is not a truly exogenous predictor. Instead, it could be that state A borrowed from model legislation, so state B, by borrowing from state A, is actually borrowing in part from an interest group model bill. Previous scholarship has provided evidence that this is indeed how the process unfolds (Garrett \& Jansa 2015). It 
could also be the case that all states are borrowing from the model bill, and therefore only appear to be borrowing from each other through the nature of our research design. Our approach assumes that the existence of model legislation would create more borrowing overall without explicitly modeling the decision of whether to borrow from peer bills or interest group model bills. We believe this is a safe assumption and should not affect the central claim of the paperthat greater legislative professionalism leads to more reinvention, and less borrowing, all else equal. But, for this claim to hold we need to be sure that states' tendency to borrow more language on policies with model legislation are not driving our results. In order to examine this possibility, we re-ran our models from table 2 after splitting our sample of policies into those with and without model legislation.

We present the coefficient estimates from the second-stage of the re-estimated model 2 in Figure 3 using the split-sample. ${ }^{24}$ We find that for policies with and without model legislation, professionalism is still a significant predictor of less-borrowing overall. We can infer that, if presented with a model bill, or with a policy diffusing across the states based on a model bill, a professional legislature is significantly more likely to make changes to the policy than a citizen legislature. The effect size mirrors what was found in the overall sample. ${ }^{25}$

[Figure 3 about here.]

\section{Discussion and Implications}

This study provides evidence that reducing the resources available to lawmakers for policymaking incentivizes lawmakers to copy and paste language from previous adopters, and therefore disincentivizes policy reinvention. We find that citizen legislatures copy more language from previous adopters, while more professional legislatures have greater capacity to reinvent diffusing policies for their jurisdictions. The principal reason for this increased reinvention capacity appears to be higher staff expenditures, though we cannot rule out that session length and salary play a role as well.

Similar to Carley et al. (2016), our study takes a step in the direction of explaining how variation across states leads to greater or less reinvention, rather than explaining how com- 
prehensive policies become over time. Existing studies of reinvention tend to examine the reinvention of single policies as they diffuse across states (Carley et al. 2016; Glick and Hays 1991; Mooney and Lee 1995; Taylor et al. 2012, though see Hays 1996). In contrast, our study examines the diffusion and reinvention of 12 policies over time.

Our study also introduces a new technique for measuring policy reinvention, using cosine similarity scores to calculate a continuous measure of text copying. Cosine similarity provides an objective measurement of reinvention by taking the bill text in its entirety into account. The methodological framework could be expanded to language adoption in other venues, such as in the initiative or referendum process, or in bureaucratic rulemaking.

Our results suggest that scholars of legislative politics should pay greater attention to the role of expediency in the policymaking process. Conventional accounts of lawmaking tend to portray policy outcomes as the result of focused bargaining that satisfies the preferences of a legislative majority. In contrast, the results here suggest that lawmakers, especially when facing resource constraints and competing demands on their attention, are willing to implement quick fixes to complex problems.

The factors that affect legislative capacity for independent policymaking are important to understand. Increasingly, journalistic and scholarly attention has focused on problems created by underresourced democratic institutions (e.g. Drutman 2015; Klein 2015; Lindsey \& Teles 2017). Independent policymaking capacity is necessary for a legislature to be insulated from undue influence of outside sources (Drutman 2014), and to effectively represent their citizens in the policy process. While legislatures with more funding for staff have a greater ability to research, deliberate, and innovate when creating policy solutions for difficult social and economic problems, legislatures that have reduced or restrained staff expenditures are more likely to depend on the innovations formulated in other states, and for other citizens, in different circumstances. Yet, additional spending on legislative institutions is unlikely to be met with popular support, with trust in government at all time lows and state budgets already strained. Nonetheless, it remains important to understand that diminishing spending on legislatures and their staffs has consequences for their ability to fully function as independent democratic institutions. 


\section{Notes}

${ }^{1}$ These provisions had previously been passed, using similar language, in South Carolina and Texas, respectively.

${ }^{2}$ Information for this example from Griffin. 2015. "Religious Freedom Restoration Acts." NCSL Legisbrief. Accessed online at http://ncsl.org/documents/legisbriefs/2015/lb2317.pdf, February 9, 2018; Cook and Eason. 2015. "Governor Mike Pence signs RFRA fix." Indianapolis Star. Accessed online at https://www.indystar.com/story/news/politics/2015/04/01/indianarfra-deal-sets-limited-protections-for-lgbt/70766920/, February 7, 2018; Kim. 2015. "Indiana Pizza Restaurant Says It Wouldn't Cater a Gay Wedding, Supports Religious Freedom Law." ABC News. Accessed online at http://abcnews.go.com/Business/indiana-pizza-restaurant-catergay-wedding-supports-religious/story?id=30045085, February 7, 2018.

${ }^{3}$ Associated Press. 2014. "Mo. Governor Vetoes Bill Requiring Criminal Background Checks For Obamacare Navigators." Associated Press. Accessed online at http://stlouis.cbslocal.com/2014/07/ governor-vetoes-bill-requiring-criminal-background-checks-for-obamacare-navigators/, September 29, 2017.

${ }^{4}$ Hays (1996) suggests less professional legislatures reinvent more, but finds inconclusive evidence in support of the hypothesis based on the diffusion of three policies: child abuse protections, victim compensation, and public campaign funding.

${ }^{5}$ Tables 8 and 9 in the Appendix provide the list of states that adopted and the year in which they adopted.

${ }^{6}$ Sampling in this manner gave use variation in ideology (4 conservative policies, 4 liberal policies, 4 moderate policies), issue type (6 economic policies, 6 social policies), model legislation (6 with model legislation, 6 without), time periods (as early as 1982 and as late as 2014) and diffusion speed (in as little as 2 years or as many as 27 years).

${ }^{7}$ While some interest groups and interstate organizations make their model legislation publicly available on their websites, others deliberately keep their model legislation private. To identify model legislation associated with each of our twelve policies, we conducted web searches, reviewed media coverage of legislative debates, and in one case contacted a lobbyist to confirm our suspicions about the presence of model legislation. We cannot be absolutely certain that no model legislation exists for the six policies we code as lacking it. However, for these six policies we could find no evidence that political organizations created relevant model legislation.

${ }^{8}$ When original bill language was not available online, we used the language from the state session law corresponding to the bill.

${ }^{9}$ Each text file was scrubbed of idiosyncrasies including numbers, symbols, punctuation, general whitespace, and bill preambles when applicable. We also converted all words to lowercase letters and removed common English stopwords like "the" and "of."

${ }^{10}$ This was done using the tm, smdc, stringr packages in $R$, which produces an adjacency matrix of similarity scores by comparing each bill text to every other bill text. A separate 
matrix was produced for each issue.

${ }^{11}$ O'Connor (2012) explains that cosine similarity can be thought of as a normalized inner product or a correlation between vectors of paired samples.

${ }^{12}$ Literally, the similarity scores are the cosine of the angle between the two vectors of words, hence the name cosine similarity. The smaller the score, the larger is the angle between the two texts, and the less similar are the two texts. This interpretation is less intuitive, but can be used to graph the similarity of texts in Euclidean space.

${ }^{13}$ First adopters are assigned similarity values of " 0, " as there is no previous adopter.

${ }^{14} \mathrm{~A}$ potential concern with this method is that it constitutes selection on the dependent variable. However, we do not limit our sample based on likely instances of copying. Rather, we use a consistent rule for measuring the potential for copying across all observations of bill adoption in the second stage. Even the most likely instance of copying for the state does not mean the obtained score suggests that copying is likely. The values of similarity scores in the second stage of our model range from 0 to 100, and the median similarity score is 0.65 -meaning the second stage contains bills ranging from exact replicas of previous bills to bills that share very little in common with any other bill.

${ }^{15}$ The mean similarity score for all policies is 0.63 and for safe haven laws is 0.59.

${ }^{16}$ We multiply Squire's index by 10 in the following results to make interpretation of the coefficient estimates easier.

${ }^{17}$ Descriptive statistics of all model variables are available in Table 5 in the Appendix

${ }^{18}$ California's 1994 adoption of the Three Strikes law is omitted from these results because the law was adopted by citizen initiative, rather than through the legislative process.

${ }^{19}$ We found systematic differences in the amount of average text copying across our twelve policies. To make sure these differences were not distorting our results, we also ran each model with fixed effects by policy in the first stage, second stage, and both stages. The inclusion of fixed effects makes few differences to the substantive results. In the appendix, we illustrate the variation in average copying across policies in Figure 4 and provide the results of the fixed effects models in Table 3 in the Appendix.

${ }^{20}$ In Table 6 of the Appendix, we present results using a measure of party control and party distance rather than government ideology. The results remain largely similar using this measure.

${ }^{21}$ Unlike Squire's measure, the Bowen and Greene measure is time-dynamic. There are 32 observations (or 8\%) missing from the Bowen and Greene measure. These are unable to be imputed in a Heckman selection model.

${ }^{22}$ To be sure our results weren't being driven by California's high professionalism, we reestimated the models without California. The models without California produced the same substantive results.

${ }^{23}$ We examined the variance inflation factor (VIF) for each of the professionalism components in Model 6, Stage 2 to assess the severity of multicollinearity between each measure. Severe 
multicollinearity could lead to inflated standard errors and, therefore, could be driving the statistically insignificant coefficient estimates for session length and salary. The VIFs for staff expenditures (VIF $=1.99)$, session length $(\mathrm{VIF}=1.81)$, and salary (VIF $=2.64$ ) were not severe enough to explain the non-significant coefficient estimates for session length and salary. A VIF of 10 or higher is considered severe.

${ }^{24}$ We focus on Model 2 because it was the best fitting and most parsimonious model, though we obtained similar results to those presented in table 2 for models $1,3,4,5$, and 6 as well.

${ }^{25}$ The full results for the re-estimated model 2 are presented in table 7 in the Appendix. 


\section{References}

Balla, S. J. (2001). Interstate professional associations and the diffusion of policy innovations. American Politics Research, $39(3), 221-45$.

Baybeck, B., Berry, W. D., \& Siegel, D. A. (2011). A strategic theory of policy diffusion via intergovernmental competition. Journal of Politics, 73(1), 232-47.

Berry, F. S., \& Berry, W. D. (1990). State lottery adoptions as policy innovations: An event history analysis. The American Political Science Review, 84(2), 395-415.

Berry, W. D., \& Baybeck, B. (2005). Using geographic information systems to study interstate competition. American Political Science Review, 99(4), 505-519.

Berry, W. D., Ringquist, E. J., Fording, R. C., \& Hanson, R. L. (1998). Measuring citizen and government ideology in the american states, 1960-93. American Journal of Political Science, 42(1), 327-348.

Boehmke, F. J. (2009). Approaches to modeling the adoption and diffusion of policies with multiple components. State Politics \& Policy Quarterly, 9(2), 229-52.

Boehmke, F. J., \& Skinner, P. (2012). State policy innovativeness revisited. State Politics $\&$ Policy Quarterly, 12(3), 303-329.

Boehmke, F. J., \& Witmer, R. (2004). Disentangling diffusion: The effects of social learning and economic competition on state policy innovation and expansion. Political Research Quarterly, 57(1), 39-51.

Boushey, G. (2010). Policy diffusion dynamics in america. New York: Cambridge University Press.

Bowen, D. C., \& Greene, Z. (2014). Should we measure professionalism with an index? a note on theory and practice in state legislative professionalism research. State Politics and Policy Quarterly, 14(3), 277-96.

Carey, J. M., Niemi, R. G., Powell, L. W., \& Moncrief, G. F. (2006). The effects of term limits on state legislatures: A new survey of the 50 states. Legislative Studies Quarterly, 31, 105-34.

Carley, S., Nicholson-Crotty, S., \& Miller, C. J. (2016). Adoption, reinvention and amendment of renewable portfolio standards in the american states. Journal of Public Policy, Forthcoming.. (Published online January 20, 2016.)

Carnes, N., \& Hansen, E. R. (2016). Does paying politicians more promote economic diversity in legislatures? American Political Science Review, 110(4), 699-716.

Clark, J. (1985). Policy diffusion and program scope: Research directions. Publius: The Journal of Federalism, 15(4), 61-70.

Clark, J., \& French, J. L. (1984). Innovation and program content in state tax policies. State 86 Local Government Review, 16(1), 11-16.

Desmarais, B., Harden, J. J., \& Boehmke, F. J. (2015). Persistent policy pathways: Inferring diffusion networks in the american states. American Political Science Review, 109(2), 392-406.

Drutman, L. (2014). Evaluating reforms of lobbying and money in politics. In M. Grossmann (Ed.), New directions in interest group politics. New York: Routledge.

Drutman, L. (2015). The business of america is lobbying. London: Oxford University Press. Fenno, R. F. (1978). Home style: House members in their districts. Boston: Little, Brown.

Garrett, K. N., \& Jansa, J. M. (2015). Interest group influence in policy diffusion networks. State Politics 8 Policy Quarterly, 15(3), 387-417.

Gilardi, F. (2016). Four ways we can improve policy diffusion research. State Politics $E_{3}$ Policy 
Quarterly, 16(1), 8-21.

Glick, H. R., \& Hays, S. P. (1991). Innovation and reinvention in state policymaking: Theory and the evolution of living will laws. Journal of Politics, 53(3), 835-50.

Gray, V. (1973). Innovation in the states: A diffusion study. American Political Science Review, $67(4), 1174-1185$.

Grossback, L. J., Nicholson-Crotty, S., \& Peterson, D. A. M. (2004). Ideology and learning in policy diffusion. American Politics Research, 32, 521-545.

Haider-Markel, D. P. (2001). Policy diffusion as a geographical expansion of the scope of political conflict: Same-sex marriage bans in the 1990s. State Politics $\&$ Policy Quarterly, 1(1), $5-26$.

Hays, S. P. (1996). Influences on reinvention during the diffusion of innovations. Political Research Quarterly, 49(3), 631-50.

Heckman, J. A. (1979). Sample selection bias as a specification error. Econometrica, 47 , 153-161.

Hertel-Fernandez, A. (2014). Who passes business's "model bills"? policy capacity and corporate influence in u.s. state politics. Perspectives on Politics, 12(3), 582-602.

Hertel-Fernandez, A., \& Kashin, K. (2015, April 16-19). Capturing business power across the states with text reuse. Chicago, April 16-19.

Ka, S., \& Teske, P. (2002). Ideology and professionalism: Electricity regulation and deregulation over time int he american states. American Politics Research, 30(3), 323-43.

Karch, A. (2007). Democratic laboratories: Policy diffusion among the american states. Ann Arbor: University of Michigan Press.

Karch, A., Nicholson-Crotty, S. C., Woods, N. D., \& Bowman., A. O. (2016). Policy diffusion and the pro-innovation bias. Political Research Quarterly, 69(1), 83-95.

Klein, E. (2015). Corporations now spend more lobbying congress than taxpayers spend funding congress. (Accessed online at https://www.vox.com/2015/4/20/8455235/congresslobbying-money-statistic, August 27, 2017)

Kousser, T. (2005). Term limits and the dismantling of legislative professionalism. New York: Cambridge University Press.

Kousser, T., \& Phillips, J. (2009). Who blinks first? legislative patience and bargaining with governors. Legislative Studies Quarterly, 34(1), 55-86.

Kroeger, M. (2015, May 28-30). Plagiarizing policy: Model legislation in state legislatures. Sacramento, CA, May 28-30.

Lee, F. E. (2009). Beyond ideology: Politics, principles, and partisanship in the u.s. senate. Chicago: University of Chicago Press.

Lindsey, B., \& Teles, S. M. (2017). The captured economy: How the powerful enrich themselves, slow down growth, and increase inequality. Oxford University Press.

Maggetti, M., \& Gilardi, F. (2015). Problems (and solutions) in the measurement of policy diffusion mechanisms. Journal of Public Policy, 36(1), 87-107.

Mooney, C. Z. (2001). Modeling regional effects on state policy diffusion. Political Research Quarterly, 54, 103-124.

Mooney, C. Z., \& Lee, M.-H. (1995). Legislative morality in the american states: The case of pre-roe abortion regulation reform. American Journal of Political Science, 39(3), 599627.

O'Connor, B. (2012). Cosine similarity, pearson correlation, and ols coefficients. AI and Social Science Blog. (Web. Accessed May 12, 2015 at http://brenocon.com/blog/2012/03/cosine-similarity-pearson-correlation-and-ols- 
coefficients/)

Pacheco, J. (2012). The social contagion model: Exploring the role of public opinion on the diffusion of antismoking legislation across the american states. Journal of Politics, 74, 187-202.

Potthast, M., Stein, B., Eiselt, A., Barron-Cedeno, A., \& Rosso, P. (2011). Overview of the 3rd international competition on plagiarism detection. In V. Petras \& P. Clough (Eds.), Notebook papers of clef 2011 labs and workshops. Amsterdam, September 19-22.

Shipan, C. R., \& Volden, C. (2006). Bottom-up federalism: The diffusion of antismoking policies from u.s. cities to states. American Journal of Political Science, 50(4), 825-43.

Shipan, C. R., \& Volden, C. (2008). The mechanisms of policy diffusion. American Journal of Political Science, 52(4), 840-57.

Shipan, C. R., \& Volden, C. (2014). When the smoke clears: Expertise, learning, and policy diffusion. Journal of Public Policy, 34 (3), 357-87.

Squire, P. (1992). Legislative professionalization and membership diversity in state legislatures. Legislative Studies Quarterly, 17(1), 69-79.

Squire, P. (2007). Measuring state legislative professionalism: The squire index revisited. State Politics and Policy Quarterly, 7, 211-227.

Taylor, J. K., Lewis, D. C., Jacobsmeier, M. L., \& DiSarro, B. (2012). Content and complexity in policy reinvention and diffusion: Gay and transgender-inclusive laws against discrimination. State Politics \& Policy Quarterly, 12(1), 75-98.

Volden, C. (2006). States as policy laboratories: Emulating success in the children's health insurance program. American Journal of Political Science, 50(2), 294-312.

Volden, C., Ting, M. M., \& Carpenter, D. P. (2008). A formal model of learning and policy diffusion. American Political Science Review, 102(3), 319-32.

Walker, J. L. (1969). The diffusion of innovations among the american states. American Political Science Review, 63(3), 880-99.

Zhelonkin, M., Genton, M. G., \& Ronchetti, E. (2016). Robust inference in sample selection models. Journal of the Royal Statistical Society, Series B (Statistical Methodology), 78(4), 805-27. 


\section{Appendix}

[Figure 4 about here.]

[Table 3 about here.]

[Table 4 about here.]

[Table 5 about here.]

[Table 6 about here.]

[Table 7 about here.]

[Table 8 about here.]

[Table 9 about here.] 


\section{Texas 1999 safe haven law}

An emergency medical services provider licensed under Chapter 773, Health and Safety Code, shall, without a court order, take possession of a child who is $\mathbf{3 0}$ days old or younger if the child is voluntarily delivered to the provider by the child's parent and the parent did not express an intent to return for the child. An emergency medical services provider who takes possession of a child under this section shall perform any act necessary to protect the physical health or safety of the child.

\section{Indiana $\mathbf{2 0 0 0}$ safe haven law}

An emergency medical services provider shall, without a court order, take custody of a child who is, or who appears to be, not more than $\mathbf{3 0}$ days of age if: the child is voluntarily left with the provider by the child's parent; and the parent does not express an intent to return for the child. An emergency medical services provider who takes custody of a child under this section shall perform any act necessary to protect the child's physical health or safety. Any person who in good faith voluntarily leaves a child with an emergency medical services provider is not obligated to disclose the parent's name or the person's name.

Note: Cosine similarity between these two bills is 0.71 , or 0.29 from a perfect match. 


\section{Florida 2005 stand your ground law}

A person is presumed to have held a reasonable fear of imminent peril of death or great bodily harm to himself or herself or another when using defensive force that is intended or likely to cause death or great bodily harm to another if: the person against whom the defensive force was used was in the process of unlawfully and forcefully entering, or had unlawfully and forcibly entered, a dwelling, residence, or occupied vehicle, or if that person had removed or was attempting to remove another against that person's will from the dwelling, residence, or occupied vehicle; and the person who uses defensive force knew or had reason to believe that an unlawful and forcible entry or unlawful and forcible act was occurring or had occurred.

\section{Oklahoma 2011 stand your ground law}

A person or an owner, manager or employee of a business is presumed to have held a reasonable fear of imminent peril of death or great bodily harm to himself or herself or another when using defensive force that is intended or likely to cause death or great bodily harm to another if: the person against whom the defensive force was used was in the process of unlawfully and forcefully entering, or had unlawfully and forcibly entered, a dwelling, residence, occupied vehicle, or a place of business, or if that person had removed or was attempting to remove another against the will of that person from the dwelling, residence, occupied vehicle, or place of business; and the person who uses defensive force knew or had reason to believe that an unlawful and forcible entry or unlawful and forcible act was occurring or had occurred.

Note: Cosine similarity between these two bills is 0.88 , or 0.12 from a perfect match. 
Figure 3: Estimated Effect of Professionalism on Text Borrowing, for Policies with and without Model Legislation

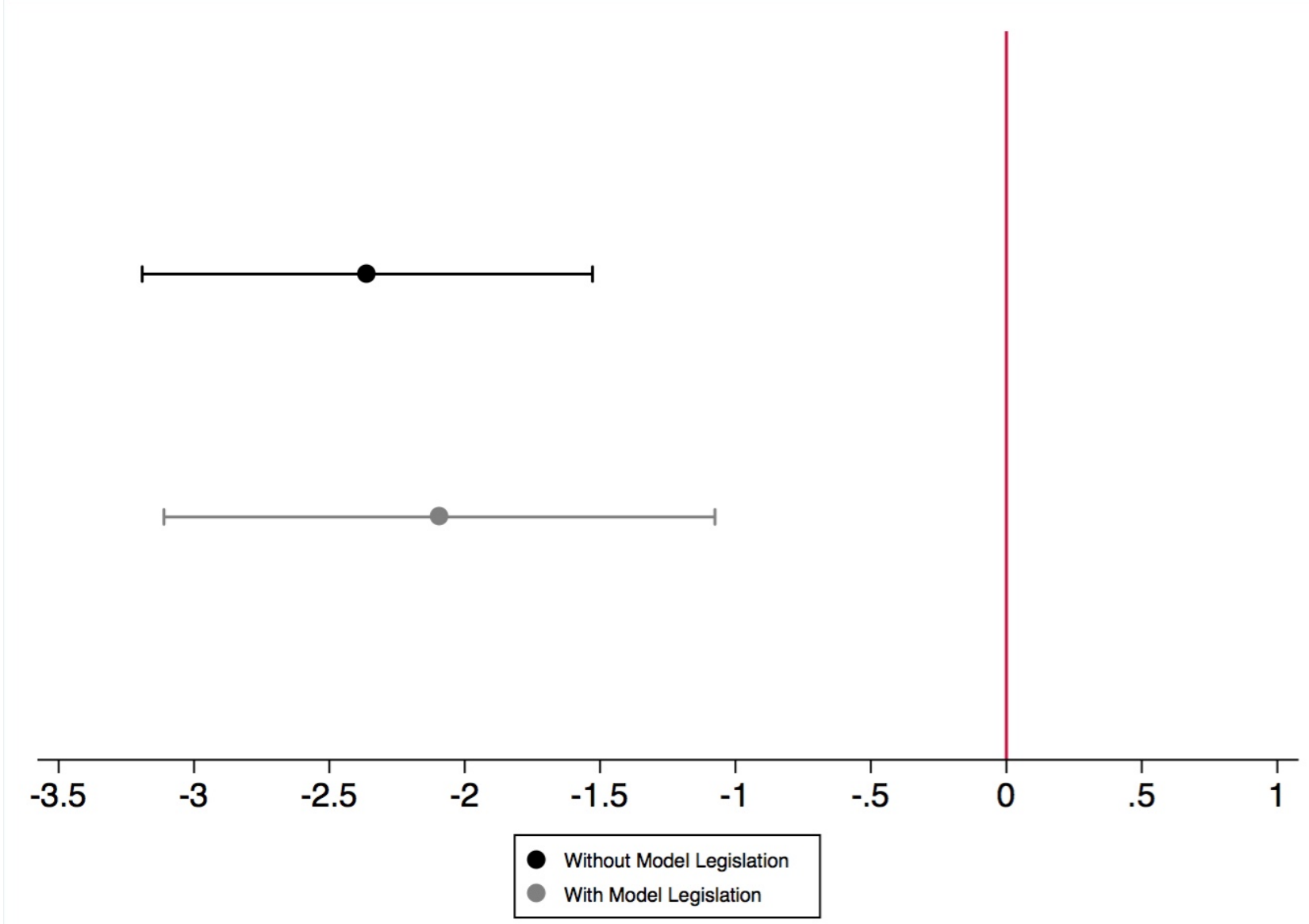

Note: Circles represent the coefficient estimate for each variable. Capped lines represent the confidence intervals at the $95 \%$ level of confidence. Coefficient estimates from the second stage of Heckman selection model. Second stage dependent variable is similarity score. See Table 7 in the Appendix for the full results. 
Figure 4: Average Cosine Similarity by Policy

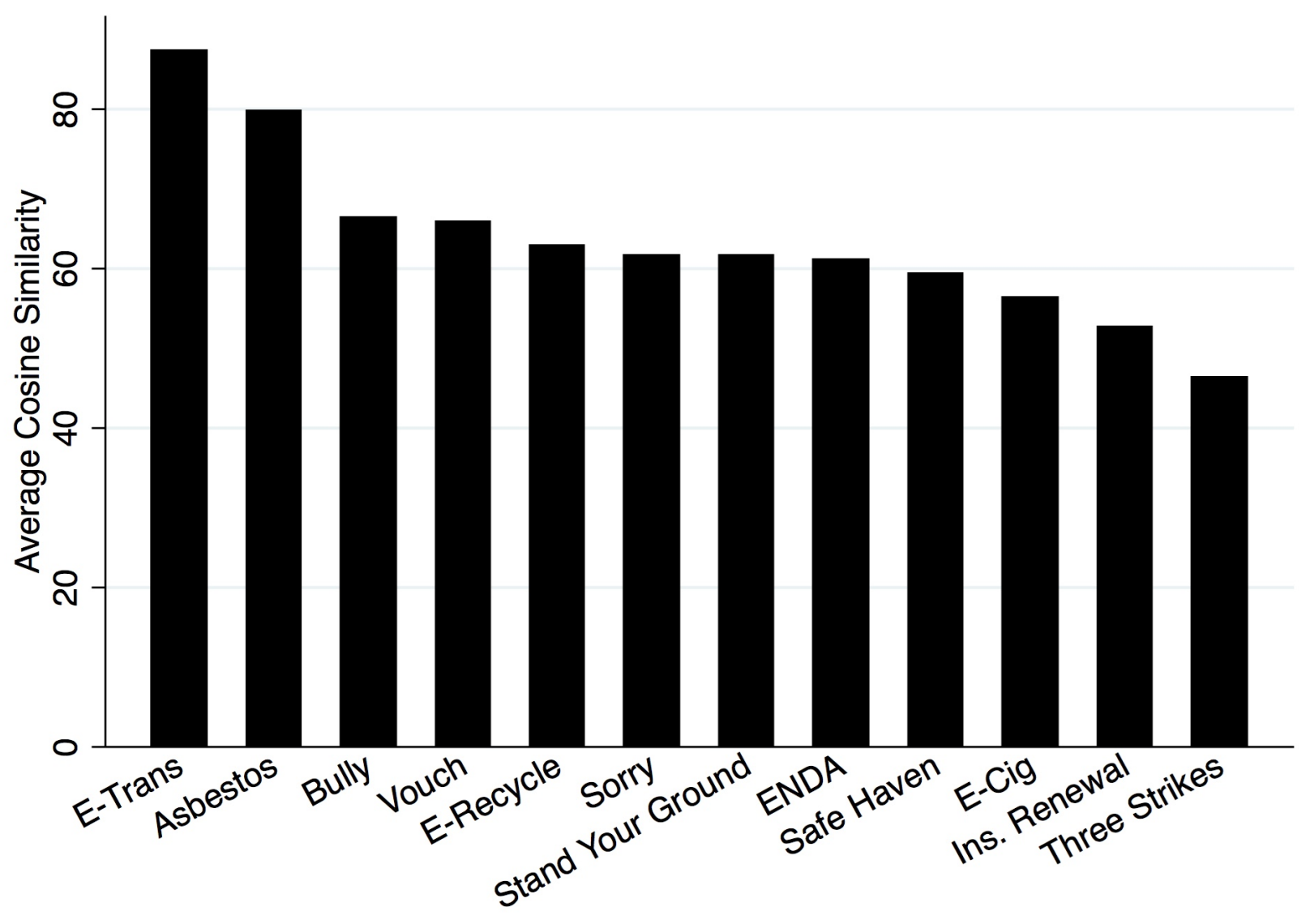


Table 1: Policy Descriptions

\begin{tabular}{|c|c|c|}
\hline Policy & Years & Description \\
\hline Asbestos Transparency & 2013-2014 & $\begin{array}{l}\text { Requires victims of asbestos exposure to disclose personal information when } \\
\text { making compensation claims. Model bill by ALEC. }\end{array}$ \\
\hline Anti-bullying & $1999-2014$ & $\begin{array}{l}\text { Mandates that school districts adopt an anti-bullying policy and lists which } \\
\text { minority groups (if any) will be specifically protected. Model bill by GLSEN }\end{array}$ \\
\hline Stand Your Ground & $2005-2014$ & $\begin{array}{l}\text { Allows individuals to use deadly force in self-defense, and specifies the loca- } \\
\text { tions where an individual may use deadly force. Model bill by ALEC. }\end{array}$ \\
\hline $\begin{array}{l}\text { Electronic Transac- } \\
\text { tions }\end{array}$ & 1999-2009 & $\begin{array}{l}\text { Institutes best practices for electronic transactions, such as recognizing the } \\
\text { legitimacy of electronic signatures on contracts and other legal agreements. } \\
\text { Model bill by NCCUSL. }\end{array}$ \\
\hline E-Cigarette Bans & 2009-2014 & Prohibits the sale of e-cigarettes to minors. Model bill by Reynolds American. \\
\hline E-Waste Recycling & 2003-2011 & $\begin{array}{l}\text { Regulates the recycling of televisions, computers, batteries, and other used } \\
\text { electronics. Specifies the conditions in which the manufacturer and/or con- } \\
\text { sumer would assume the costs of collection and disposal. Model bill by Dell } \\
\text { and Electronic TakeBack. }\end{array}$ \\
\hline Three Strikes & 1993-1995 & Prescribes life sentences to individuals with three felony convictions. \\
\hline I'm Sorry Laws & 1986-2014 & $\begin{array}{l}\text { Specifies that apologies from medical professionals are not necessarily admis- } \\
\text { sions of guilt and is not sufficient evidence for being found guilty of malprac- } \\
\text { tice. }\end{array}$ \\
\hline Safe Haven Laws & $1999-2008$ & $\begin{array}{l}\text { Allows fire fighters and other emergency medical personnel to assume tempo- } \\
\text { rary custody of abandoned babies. Provides protections for individuals who } \\
\text { leave babies with authorities. Specifies the proper procedure for turning the } \\
\text { baby over to child protective services. }\end{array}$ \\
\hline $\begin{array}{l}\text { Guaranteed Insurance } \\
\text { Renewal }\end{array}$ & $1992-1998$ & $\begin{array}{l}\text { Requires insurance companies to renew insurance policies regardless of the } \\
\text { policyholder's claim history. }\end{array}$ \\
\hline School Vouchers & $1990-2013$ & $\begin{array}{l}\text { Programs that allow students to pay for private schooling using public funds } \\
\text { under certain conditions, such as inadequate public schools or special educa- } \\
\text { tion needs. }\end{array}$ \\
\hline $\begin{array}{l}\text { LGBT Employment } \\
\text { Nondiscrimination }\end{array}$ & 1982-2009 & $\begin{array}{l}\text { Prevents employers from discriminating against employees due to their sexual } \\
\text { orientation. }\end{array}$ \\
\hline
\end{tabular}

Note $:$ ALEC $=$ American Legislative Exchange Council; GLSEN = Gay, Lesbian, and Straight Education Network; NCCUSL $=$ National Conference of Commissioners on Uniform State Laws. 
Table 2: Selection Model of Policy Language Diffusion

\begin{tabular}{|c|c|c|c|c|c|c|}
\hline & (Model 1) & (Model 2) & (Model 3) & (Model 4) & (Model 5) & (Model 6) \\
\hline & \multicolumn{6}{|c|}{ Stage 1: $D V=$ Adopted Policy } \\
\hline Ideological & $-0.63^{*}$ & $-0.59^{*}$ & $-0.62^{*}$ & $-0.59^{*}$ & $-0.63^{*}$ & $-0.59^{*}$ \\
\hline Distance & $(0.17)$ & $(0.17)$ & $(0.17)$ & $(0.17)$ & $(0.17)$ & $(0.17)$ \\
\hline Government & $-0.68^{*}$ & $-0.69^{*}$ & $-0.69^{*}$ & $-0.69^{*}$ & $-0.69^{*}$ & $-0.70^{*}$ \\
\hline Ideology & $(0.19)$ & $(0.20)$ & $(0.20)$ & $(0.19)$ & $(0.19)$ & $(0.17)$ \\
\hline \multirow[t]{2}{*}{ Model Legislation } & $0.22^{*}$ & $0.25^{*}$ & $0.23^{*}$ & $0.26^{*}$ & $0.23^{*}$ & $0.25^{*}$ \\
\hline & $(0.07)$ & $(0.08)$ & $(0.07)$ & $(0.08)$ & $(0.07)$ & $(0.08)$ \\
\hline \multirow[t]{2}{*}{ Border } & $0.69^{*}$ & $0.67^{*}$ & $0.69^{*}$ & $0.67^{*}$ & $0.69^{*}$ & $0.68^{*}$ \\
\hline & $(0.07)$ & $(0.07)$ & $(0.07)$ & $(0.08)$ & $(0.07)$ & $(0.07)$ \\
\hline Per Capita Income & $0.20^{*}$ & $0.19^{*}$ & $0.20^{*}$ & $0.18^{*}$ & $0.20^{*}$ & $0.19^{*}$ \\
\hline (in $\$ 10,000$ s) & $(0.05)$ & $(0.06)$ & $(0.05)$ & $(0.06)$ & $(0.05)$ & $(0.06)$ \\
\hline \multirow[t]{2}{*}{ Time } & -0.01 & -0.01 & -0.01 & -0.01 & -0.01 & -0.01 \\
\hline & $(0.01)$ & $(0.02)$ & $(0.01)$ & $(0.02)$ & $(0.05)$ & $(0.02)$ \\
\hline \multirow[t]{2}{*}{ Time $^{2}$} & -0.00 & -0.00 & -0.00 & -0.00 & -0.00 & -0.00 \\
\hline & $(0.00)$ & $(0.00)$ & $(0.00)$ & $(0.00)$ & $(0.00)$ & $(0.00)$ \\
\hline \multirow[t]{3}{*}{ Constant } & $-1.89^{*}$ & $-1.95^{*}$ & $-1.90^{*}$ & $-1.92^{*}$ & $-1.90^{*}$ & $-1.94^{*}$ \\
\hline & $(0.20)$ & $(0.21)$ & $(0.20)$ & $(0.21)$ & $(0.20)$ & $(0.21)$ \\
\hline & \multicolumn{6}{|c|}{ Stage 2: $D V=$ Similarity Score } \\
\hline Professionalism & $-3.49^{*}$ & & & & & \\
\hline (Squire) & $(0.64)$ & & & & & \\
\hline \multirow{2}{*}{\multicolumn{2}{|c|}{$\begin{array}{l}\text { Professionalism } \\
\text { (Bowen \& Greene) }\end{array}$}} & $-2.33^{*}$ & & & & \\
\hline & & $(0.39)$ & & & & \\
\hline \multirow{2}{*}{\multicolumn{2}{|c|}{$\begin{array}{l}\text { Staff } \\
\text { Expenditures (in } \$ 100 \text { s) }\end{array}$}} & & $-0.48^{*}$ & & & $-0.39^{*}$ \\
\hline & & & $(0.07)$ & & & $(0.13)$ \\
\hline \multicolumn{2}{|l|}{$\begin{array}{l}\text { Session } \\
\text { Length }\end{array}$} & & & $-0.03^{*}$ & & -0.00 \\
\hline Length & & & & $(0.01)$ & & $(0.01)$ \\
\hline \multirow{2}{*}{$\begin{array}{l}\text { Salary } \\
\text { (in } \$ 1000 \text { s) }\end{array}$} & & & & & $-0.07^{*}$ & -0.02 \\
\hline & & & & & $(0.02)$ & $(0.03)$ \\
\hline \multirow[t]{2}{*}{ Term Limits } & 3.25 & 3.39 & 3.72 & 2.68 & 3.51 & 3.54 \\
\hline & $(2.26)$ & $(2.27)$ & $(2.30)$ & $(2.34)$ & $(2.31)$ & $(2.27)$ \\
\hline \multirow[t]{2}{*}{ Time } & $0.87^{*}$ & $0.84^{*}$ & $0.87^{*}$ & $0.83^{*}$ & $0.90^{*}$ & $0.84^{*}$ \\
\hline & $(0.19)$ & $(0.19)$ & $(0.19)$ & $(0.20)$ & $(0.19)$ & $(0.19)$ \\
\hline \multirow[t]{2}{*}{ Order } & $0.40^{*}$ & $0.42^{*}$ & $0.39^{*}$ & $0.43^{*}$ & $0.39^{*}$ & $0.41^{*}$ \\
\hline & $(0.12)$ & $(0.13)$ & $(0.12)$ & $(0.14)$ & $(0.12)$ & $(0.12)$ \\
\hline \multirow[t]{2}{*}{ Model Legislation } & $9.63^{*}$ & $9.19^{*}$ & $9.96^{*}$ & $8.64^{*}$ & $9.81^{*}$ & $9.45^{*}$ \\
\hline & $(1.73)$ & $(1.86)$ & $(1.78)$ & $(2.00)$ & $(1.74)$ & $(1.87)$ \\
\hline \multirow[t]{2}{*}{ Constant } & $71.42^{*}$ & $64.14^{*}$ & $67.27^{*}$ & $70.43^{*}$ & $68.97^{*}$ & $67.39^{*}$ \\
\hline & $(9.37)$ & $(10.66)$ & $(9.30)$ & $(11.68)$ & $(9.76)$ & $(10.22)$ \\
\hline \multirow{3}{*}{$\begin{array}{l}\text { Observations } \\
\text { Uncensored Obs. } \\
\text { BIC }\end{array}$} & 5263 & 5263 & 5263 & 5263 & 5263 & 5263 \\
\hline & 384 & 356 & 382 & 356 & 382 & 356 \\
\hline & 5986.38 & 5609.51 & 5956.34 & 5617.58 & 5961.28 & 5624.74 \\
\hline \multirow[t]{2}{*}{ Inverse Mills Ratio } & $-10.82^{*}$ & $-10.14^{*}$ & $-10.29^{*}$ & $-11.37^{*}$ & $-11.12^{*}$ & $-9.812^{*}$ \\
\hline & $(4.67)$ & $(5.13)$ & $(4.68)$ & $(5.70)$ & $(4.78)$ & $(4.97)$ \\
\hline
\end{tabular}

Note: ${ }^{*} \mathrm{p} \leq .05$. Robust clustered standard errors are in parentheses. Significance tests are two-tailed. Differences in N-size in the second stage due to missing values from Bowen and Greene's (2014) data. 
Table 3: Selection Model of Policy Language Diffusion with Policy Fixed Effects

\begin{tabular}{|c|c|c|c|c|c|c|}
\hline & (Model 1) & (Model 2) & (Model 3) & (Model 4) & (Model 5) & (Model 6) \\
\hline & \multicolumn{6}{|c|}{ Stage 1: DV = Adopted Policy } \\
\hline $\begin{array}{l}\text { Ideological } \\
\text { Distance }\end{array}$ & $\begin{array}{l}-0.37^{*} \\
(0.17)\end{array}$ & $\begin{array}{l}-0.29 \\
(0.17)\end{array}$ & $\begin{array}{l}-0.34 \\
(0.18)\end{array}$ & $\begin{array}{l}-0.28 \\
(0.16)\end{array}$ & $\begin{array}{l}-0.35^{*} \\
(0.17)\end{array}$ & $\begin{array}{l}-0.31 \\
(0.18)\end{array}$ \\
\hline $\begin{array}{l}\text { Government } \\
\text { Ideology }\end{array}$ & $\begin{array}{l}-0.38 \\
(0.21)\end{array}$ & $\begin{array}{l}-0.37 \\
(0.22)\end{array}$ & $\begin{array}{l}-0.38 \\
(0.23)\end{array}$ & $\begin{array}{l}-0.35 \\
(0.21)\end{array}$ & $\begin{array}{l}-0.37 \\
(0.21)\end{array}$ & $\begin{array}{l}-0.39 \\
(0.23)\end{array}$ \\
\hline Model Legislation & $\begin{array}{l}0.24^{*} \\
(0.07)\end{array}$ & $\begin{array}{l}0.28^{*} \\
(0.08)\end{array}$ & $\begin{array}{l}0.25^{*} \\
(0.07)\end{array}$ & $\begin{array}{l}0.29^{*} \\
(0.07)\end{array}$ & $\begin{array}{l}0.25^{*} \\
(0.07)\end{array}$ & $\begin{array}{l}0.27^{*} \\
(0.08)\end{array}$ \\
\hline Border & $\begin{array}{l}0.56^{*} \\
(0.10)\end{array}$ & $\begin{array}{l}0.56^{*} \\
(0.10)\end{array}$ & $\begin{array}{l}0.57^{*} \\
(0.11)\end{array}$ & $\begin{array}{l}0.54^{*} \\
(0.10)\end{array}$ & $\begin{array}{l}0.56^{*} \\
(0.10)\end{array}$ & $\begin{array}{l}0.57^{*} \\
(0.08)\end{array}$ \\
\hline $\begin{array}{l}\text { Per Capita Income } \\
\text { (in } \$ 10,000 \text { s) }\end{array}$ & $\begin{array}{l}0.17^{*} \\
(0.05)\end{array}$ & $\begin{array}{l}0.15^{*} \\
(0.05)\end{array}$ & $\begin{array}{l}0.15^{*} \\
(0.05)\end{array}$ & $\begin{array}{l}0.13^{*} \\
(0.04)\end{array}$ & $\begin{array}{l}0.16^{*} \\
(0.05)\end{array}$ & $\begin{array}{l}0.15^{*} \\
(0.05)\end{array}$ \\
\hline Time & $\begin{array}{c}0.01 \\
(0.00)\end{array}$ & $\begin{array}{c}0.01 \\
(0.01)\end{array}$ & $\begin{array}{c}0.01 \\
(0.01)\end{array}$ & $\begin{array}{c}0.01 \\
(0.01)\end{array}$ & $\begin{array}{c}0.01 \\
(0.01)\end{array}$ & $\begin{array}{c}0.01 \\
(0.01)\end{array}$ \\
\hline Time $^{2}$ & $\begin{array}{l}-0.00^{*} \\
(0.00)\end{array}$ & $\begin{array}{l}-0.00^{*} \\
(0.00)\end{array}$ & $\begin{array}{l}-0.00^{*} \\
(0.00)\end{array}$ & $\begin{array}{l}-0.00^{*} \\
(0.00)\end{array}$ & $\begin{array}{l}-0.00^{*} \\
(0.00)\end{array}$ & $\begin{array}{l}-0.00^{*} \\
(0.00)\end{array}$ \\
\hline Constant & $\begin{array}{l}-2.03^{*} \\
(0.17)\end{array}$ & $\begin{array}{l}-2.06^{*} \\
(0.16)\end{array}$ & $\begin{array}{l}-2.00^{*} \\
(0.17)\end{array}$ & $\begin{array}{l}-2.01^{*} \\
(0.15)\end{array}$ & $\begin{array}{l}-2.03^{*} \\
(0.17)\end{array}$ & $\begin{array}{l}-2.06^{*} \\
(0.16)\end{array}$ \\
\hline $\begin{array}{l}\text { Professionalism } \\
\text { (Squire) }\end{array}$ & \multicolumn{6}{|c|}{ Stage 2: $D V=$ Similarity Score } \\
\hline $\begin{array}{l}\text { Professionalism } \\
\text { (Bowen \& Greene) }\end{array}$ & & $\begin{array}{l}-1.65^{*} \\
(0.43)\end{array}$ & & & & \\
\hline $\begin{array}{l}\text { Staff } \\
\text { Expenditures }\end{array}$ & & & $\begin{array}{l}-0.33^{*} \\
(0.10)\end{array}$ & & & $\begin{array}{l}-0.22 \\
(0.16)\end{array}$ \\
\hline $\begin{array}{l}\text { Session } \\
\text { Length }\end{array}$ & & & & $\begin{array}{l}-0.02^{*} \\
(0.01)\end{array}$ & & $\begin{array}{c}0.00 \\
(0.01)\end{array}$ \\
\hline Salary & & & & & $\begin{array}{l}-0.05^{*} \\
(0.02)\end{array}$ & $\begin{array}{l}-0.03 \\
(0.03)\end{array}$ \\
\hline Term Limits & $\begin{array}{c}3.16 \\
(1.97)\end{array}$ & $\begin{array}{c}3.29 \\
(2.09)\end{array}$ & $\begin{array}{c}3.27 \\
(2.15)\end{array}$ & $\begin{array}{c}2.77 \\
(2.09)\end{array}$ & $\begin{array}{c}3.33 \\
(2.07)\end{array}$ & $\begin{array}{c}3.38 \\
(2.11)\end{array}$ \\
\hline Time & $\begin{array}{l}1.77^{*} \\
(0.45)\end{array}$ & $\begin{array}{l}1.73^{*} \\
(0.48)\end{array}$ & $\begin{array}{l}1.74^{*} \\
(0.50)\end{array}$ & $\begin{array}{l}1.74^{*} \\
(0.50)\end{array}$ & $\begin{array}{l}1.82^{*} \\
(0.47)\end{array}$ & $\begin{array}{l}1.80^{*} \\
(0.49)\end{array}$ \\
\hline Order & $\begin{array}{l}-0.01 \\
(0.14)\end{array}$ & $\begin{array}{l}-0.04 \\
(0.14)\end{array}$ & $\begin{array}{l}-0.03 \\
(0.15)\end{array}$ & $\begin{array}{l}-0.05 \\
(0.13)\end{array}$ & $\begin{array}{l}-0.05 \\
(0.13)\end{array}$ & $\begin{array}{l}-0.05 \\
(0.14)\end{array}$ \\
\hline Model Legislation & $\begin{array}{c}7.53 \\
(9.22)\end{array}$ & $\begin{array}{c}7.14 \\
(10.31)\end{array}$ & $\begin{array}{c}6.73 \\
(11.08)\end{array}$ & $\begin{array}{c}6.69 \\
(10.25)\end{array}$ & $\begin{array}{c}7.58 \\
(9.83)\end{array}$ & $\begin{array}{c}8.65 \\
(11.01)\end{array}$ \\
\hline Policy Fixed Effects & Yes & Yes & Yes & Yes & Yes & Yes \\
\hline Constant & $\begin{array}{l}92.53^{*} \\
(15.19)\end{array}$ & $\begin{array}{l}89.59^{*} \\
(17.07)\end{array}$ & $\begin{array}{l}91.49^{*} \\
(18.54)\end{array}$ & $\begin{array}{l}94.86^{*} \\
(16.25)\end{array}$ & $\begin{array}{l}92.02^{*} \\
(16.20)\end{array}$ & $\begin{array}{l}89.34^{*} \\
(19.09)\end{array}$ \\
\hline $\begin{array}{l}\text { Observations } \\
\text { Uncensored Obs. } \\
\text { BIC }\end{array}$ & $\begin{array}{c}5263 \\
384 \\
5960.89 \\
\end{array}$ & $\begin{array}{c}5263 \\
356 \\
5580.25 \\
\end{array}$ & $\begin{array}{c}5263 \\
382 \\
5931.97 \\
\end{array}$ & $\begin{array}{c}5263 \\
356 \\
5587.04 \\
\end{array}$ & $\begin{array}{c}5263 \\
382 \\
5932.32 \\
\end{array}$ & $\begin{array}{c}5263 \\
356 \\
5595.72 \\
\end{array}$ \\
\hline Inverse Mills Ratio & $\begin{array}{c}-10.82^{*} \\
(4.67)\end{array}$ & $\begin{array}{c}-24.87^{*} \\
(5.08)\end{array}$ & $\begin{array}{c}-10.29^{*} \\
(4.68)\end{array}$ & $\begin{array}{c}-11.37^{*} \\
(5.70)\end{array}$ & $\begin{array}{c}-11.12^{*} \\
(4.77)\end{array}$ & $\begin{array}{l}-9.82^{*} \\
(4.97)\end{array}$ \\
\hline
\end{tabular}

Note: ${ }^{*} \mathrm{p} \leq .05$. Robust clustered standard errors are in parentheses. Significance tests are two-tailed. Differences in N-size in the second stage due to missing values from Bowen and Greene's (2014) data. 
Table 4: Robust Selection Model of Policy Language Diffusion

\begin{tabular}{|c|c|c|c|c|c|c|}
\hline & (Model 1) & (Model 2) & (Model 3) & (Model 4) & (Model 5) & $($ Model 6) \\
\hline & \multicolumn{6}{|c|}{ Stage 1: $D V=$ Adopted Policy } \\
\hline Ideological & $-0.50^{*}$ & $-0.50^{*}$ & $-0.50^{*}$ & $-0.50^{*}$ & $-0.50^{*}$ & $-0.50^{*}$ \\
\hline Distance & $(0.19)$ & $(0.19)$ & $(0.19)$ & $(0.19)$ & $(0.19)$ & $(0.19)$ \\
\hline Government & $-0.94^{*}$ & $-0.94^{*}$ & $-0.94^{*}$ & $-0.94^{*}$ & $-0.94^{*}$ & $-0.94^{*}$ \\
\hline Ideology & $(0.18)$ & $(0.18)$ & $(0.18)$ & $(0.18)$ & $(0.18)$ & $(0.18)$ \\
\hline \multirow[t]{2}{*}{ Model Legislation } & $0.29 *$ & $0.29^{*}$ & $0.29^{*}$ & $0.29 *$ & $0.29^{*}$ & $0.29 *$ \\
\hline & $(0.09)$ & $(0.09)$ & $(0.09)$ & $(0.09)$ & $(0.09)$ & $(0.09)$ \\
\hline \multirow[t]{2}{*}{ Border } & $0.74^{*}$ & $0.74^{*}$ & $0.74^{*}$ & $0.74^{*}$ & $0.74^{*}$ & $0.74^{*}$ \\
\hline & $(0.07)$ & $(0.07)$ & $(0.07)$ & $(0.07)$ & $(0.07)$ & $(0.07)$ \\
\hline Per Capita Income & $0.22^{*}$ & $0.22^{*}$ & $0.22^{*}$ & $0.22^{*}$ & $0.22^{*}$ & $0.22^{*}$ \\
\hline (in $\$ 10,000 \mathrm{~s}$ ) & $(0.06)$ & $(0.06)$ & $(0.06)$ & $(0.06)$ & $(0.06)$ & $(0.06)$ \\
\hline \multirow[t]{2}{*}{ Time } & -0.00 & -0.00 & -0.00 & -0.00 & -0.00 & -0.00 \\
\hline & $(0.02)$ & $(0.02)$ & $(0.02)$ & $(0.02)$ & $(0.00)$ & $(0.02)$ \\
\hline \multirow[t]{2}{*}{ Time $^{2}$} & -0.00 & -0.00 & -0.00 & -0.00 & -0.00 & -0.00 \\
\hline & $(0.00)$ & $(0.00)$ & $(0.00)$ & $(0.00)$ & $(0.00)$ & $(0.00)$ \\
\hline \multirow[t]{2}{*}{ Constant } & $-1.97^{*}$ & $-1.97^{*}$ & $-1.97^{*}$ & $-1.97^{*}$ & $-1.97^{*}$ & $-1.97^{*}$ \\
\hline & $(0.24)$ & $(0.24)$ & $(0.24)$ & $(0.24)$ & $(0.24)$ & $(0.24)$ \\
\hline & \multicolumn{6}{|c|}{ Stage 2: $D V=$ Similarity Score } \\
\hline Professionalism & $-2.18^{*}$ & & & & & \\
\hline (Squire) & $(0.82)$ & & & & & \\
\hline \multirow{2}{*}{$\begin{array}{l}\text { Professionalism } \\
\text { (Bowen \& Greene) }\end{array}$} & & $-1.48^{*}$ & & & & \\
\hline & & $(0.63)$ & & & & \\
\hline Staff & & & $-0.29^{*}$ & & & -0.21 \\
\hline Expenditures (in $\$ 100$ s) & & & $(0.14)$ & & & $(0.19)$ \\
\hline Session & & & & $-0.02^{*}$ & & -0.01 \\
\hline Length & & & & $(0.01)$ & & $(0.01)$ \\
\hline \multirow{2}{*}{$\begin{array}{l}\text { Salary } \\
\text { (in } \$ 1000 \text { s) }\end{array}$} & & & & & $-0.04^{*}$ & -0.01 \\
\hline & & & & & $(0.02)$ & $(0.03)$ \\
\hline \multirow[t]{2}{*}{ Term Limits } & $4.36^{*}$ & $4.46^{*}$ & $4.30^{*}$ & $4.29^{*}$ & $4.48^{*}$ & $4.39^{*}$ \\
\hline & $(2.01)$ & $(2.01)$ & $(1.99)$ & $(2.08)$ & $(2.01)$ & $(2.06)$ \\
\hline \multirow[t]{2}{*}{ Time } & $0.53^{*}$ & $0.52^{*}$ & $0.52^{*}$ & $0.50^{*}$ & $0.52^{*}$ & $0.52^{*}$ \\
\hline & $(0.13)$ & $(0.14)$ & $(0.14)$ & $(0.14)$ & $(0.14)$ & $(0.14)$ \\
\hline \multirow[t]{2}{*}{ Order } & $0.33^{*}$ & $0.33^{*}$ & $0.33^{*}$ & $0.34^{*}$ & $0.33^{*}$ & $0.33^{*}$ \\
\hline & $(0.09)$ & $(0.08)$ & $(0.09)$ & $(0.09)$ & $(0.09)$ & $(0.09)$ \\
\hline \multirow[t]{2}{*}{ Model Legislation } & $7.26^{*}$ & $7.34^{*}$ & $7.42^{*}$ & $7.08^{*}$ & $7.32^{*}$ & $7.38^{*}$ \\
\hline & $(2.18)$ & $(2.17)$ & $(2.15)$ & $(2.14)$ & $(2.14)$ & $(2.15)$ \\
\hline \multirow[t]{2}{*}{ Constant } & $67.18^{*}$ & $62.92^{*}$ & $64.89^{*}$ & $65.96^{*}$ & $65.32^{*}$ & $65.96^{*}$ \\
\hline & $(6.79)$ & $(6.39)$ & $(6.61)$ & $(6.59)$ & $(6.50)$ & $(6.63)$ \\
\hline \multirow[t]{2}{*}{ Inverse Mills Ratio } & $-6.55^{*}$ & $-6.28^{\dagger}$ & $-6.34^{\dagger}$ & $-6.28^{\dagger}$ & $-6.44^{*}$ & $-6.25^{\dagger}$ \\
\hline & $(3.23)$ & $(3.22)$ & $(3.26)$ & $(3.24)$ & $(3.17)$ & $(3.22)$ \\
\hline
\end{tabular}

Note: ${ }^{*} \mathrm{p} \leq .05,{ }^{\dagger} \mathrm{p} \leq .10$. Standard errors are in parentheses. Significance tests are two-tailed. 
Table 5: Descriptive Statistics for Model Variables

\begin{tabular}{r|rrrr} 
& Mean & Std. Dev. & Min & Max \\
\hline Ideological Distance & 0.31 & 0.21 & 0 & 0.86 \\
Government Ideology & 0.52 & 0.23 & 0 & 0.95 \\
Model Legislation & 0.31 & 0.46 & 0 & 1 \\
Border & 0.28 & 0.45 & 0 & 1 \\
Per Capita Income (in \$10,000s) & 3.58 & 0.65 & 1.92 & 5.95 \\
Time & 7.99 & 7.33 & 0 & 28 \\
Professionalism (Squire) & 1.7 & 1.1 & 0.27 & 6.3 \\
Professionalism (Bowen \& Greene) & -0.02 & 1.45 & -1.85 & 8.56 \\
Staff Expenditures (in \$100,000s) & 6.48 & 7.04 & 0.48 & 55.23 \\
Session Length & 145.39 & 85.98 & 36 & 549.54 \\
Salary (in \$1,000s) & 53.77 & 46.44 & 0 & 254.94 \\
Order & 14.38 & 12.30 & 0 & 49 \\
Similarity Score & 63.42 & 22.22 & 0 & 99.22 \\
\hline
\end{tabular}


Table 6: Selection Model of Policy Language Diffusion with Party Control

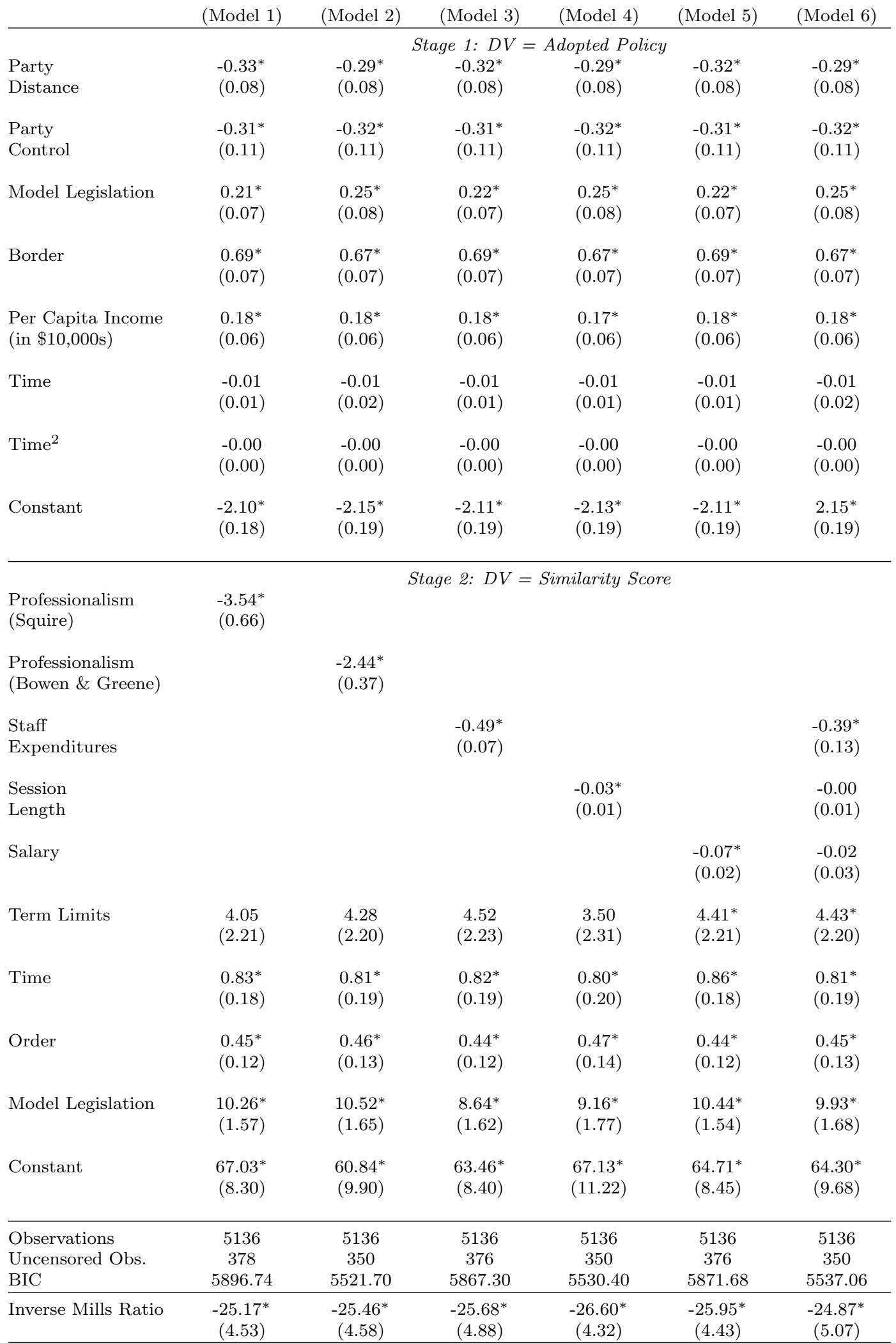

Note: ${ }^{*} \mathrm{p} \leq .05$. Robust clustered standard errors are in parentheses. Significance tests are two-tailed. Differences in N-size in the second stage due to missing values from Bowen and Greene's (2014) data. 
Table 7: Selection Models of Policy Language Diffusion, By Model Legislation Sub-Sample

\begin{tabular}{|c|c|c|}
\hline & $\begin{array}{c}\text { Policies with } \\
\text { Model Legislation }\end{array}$ & $\begin{array}{l}\text { Policies without } \\
\text { Model Legislation }\end{array}$ \\
\hline & \multicolumn{2}{|c|}{ Stage 1: $D V=$ Policy Adoption } \\
\hline $\begin{array}{l}\text { Ideological } \\
\text { Distance }\end{array}$ & $\begin{array}{l}-1.17^{*} \\
(0.24)\end{array}$ & $\begin{array}{l}-0.01 \\
(-0.22)\end{array}$ \\
\hline $\begin{array}{l}\text { Government } \\
\text { Ideology }\end{array}$ & $\begin{array}{l}-0.84^{*} \\
(0.27)\end{array}$ & $\begin{array}{l}-0.42 \\
(0.22)\end{array}$ \\
\hline Border & $\begin{array}{l}-0.01 \\
(-0.08)\end{array}$ & $\begin{array}{l}0.81^{*} \\
(0.09)\end{array}$ \\
\hline Per Capita Income & $\begin{array}{l}-0.08 \\
(0.05)\end{array}$ & $\begin{array}{l}0.43^{*} \\
(0.08)\end{array}$ \\
\hline Time & $\begin{array}{l}0.35^{*} \\
(0.04)\end{array}$ & $\begin{array}{l}-0.09^{*} \\
(0.01)\end{array}$ \\
\hline Time $^{2}$ & $\begin{array}{l}-0.02^{*} \\
(0.00)\end{array}$ & $\begin{array}{l}0.00^{*} \\
(0.00)\end{array}$ \\
\hline \multirow[t]{2}{*}{ Constant } & $\begin{array}{r}-0.89^{*} \\
(0.23) \\
\end{array}$ & $\begin{array}{r}-2.78^{*} \\
(0.32) \\
\end{array}$ \\
\hline & \multicolumn{2}{|c|}{ Stage 2: $D V=$ Similarity Score } \\
\hline $\begin{array}{l}\text { Professionalism } \\
\text { (Bowen \& Greene) }\end{array}$ & $\begin{array}{l}-2.09^{*} \\
(0.51)\end{array}$ & $\begin{array}{l}-2.36^{*} \\
(0.42)\end{array}$ \\
\hline Term Limits & $\begin{array}{c}0.99 \\
(2.39)\end{array}$ & $\begin{array}{l}10.22^{*} \\
(3.17)\end{array}$ \\
\hline Time & $\begin{array}{c}0.10 \\
(1.07)\end{array}$ & $\begin{array}{l}0.78^{*} \\
(0.19)\end{array}$ \\
\hline Order & $\begin{array}{c}0.22 \\
(0.19)\end{array}$ & $\begin{array}{l}0.40^{*} \\
(0.14)\end{array}$ \\
\hline Constant & $\begin{array}{c}107.30^{*} \\
(7.83)\end{array}$ & $\begin{array}{l}54.73^{*} \\
(9.45)\end{array}$ \\
\hline $\begin{array}{l}\text { Observations } \\
\text { Uncensored Obs. } \\
\text { BIC }\end{array}$ & $\begin{array}{c}1660 \\
188 \\
2758.77 \\
\end{array}$ & $\begin{array}{c}3959 \\
168 \\
2773.57 \\
\end{array}$ \\
\hline Inverse Mills Ratio & $\begin{array}{c}-28.38^{*} \\
(3.67) \\
\end{array}$ & $\begin{array}{l}-6.09 \\
(4.69)\end{array}$ \\
\hline
\end{tabular}

Note: ${ }^{*} \mathrm{p} \leq .05$. Robust clustered standard errors are in parentheses. Significance tests are two-tailed. 
Table 8: Policy Adoption Dates for Policies with Model Legislation

\begin{tabular}{|c|c|}
\hline Policy & Adopters (Year) \\
\hline $\begin{array}{l}\text { Asbestos } \\
\text { parency }\end{array}$ & $\begin{array}{l}\text { AZ (2015) OH (2013) OK (2013) TN (2016) TX (2015) UT (2016) } \\
\text { WI (2014) WV (2015) }\end{array}$ \\
\hline Anti-bullying & 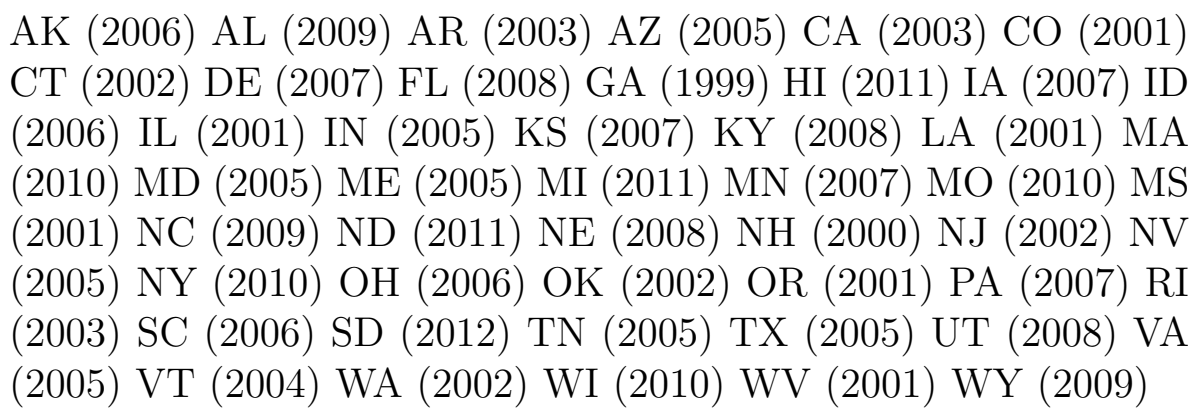 \\
\hline Stand Your Ground & $\begin{array}{l}\text { AK (2007) AL (2006) AZ (2006) CO (2012) FL (2005) GA (2006) } \\
\text { IN (2006) KS (2006) KY (2006) LA (2006) ME (2007) MI (2006) } \\
\text { MO (2010) MS (2006) MT (2009) NC (2011) ND (2007) NH (2011) } \\
\text { NJ (2012) NV (2011) OH (2008) OK (2011) PA (2011) SC (2006) } \\
\text { SD (2005) TN (2007) TX (2007) UT (2010) WA (2011) WI (2011) } \\
\text { WV (2008) }\end{array}$ \\
\hline $\begin{array}{l}\text { Electronic Transac- } \\
\text { tions }\end{array}$ & $\begin{array}{l}\mathrm{AK}(2004) \mathrm{AL}(2001) \mathrm{AR}(2001) \mathrm{AZ}(2000) \mathrm{CA}(1999) \mathrm{CO}(2002) \\
\mathrm{CT}(2002) \mathrm{DE}(2000) \mathrm{FL}(2000) \mathrm{GA}(2009) \mathrm{HI}(2000) \mathrm{IA}(2000) \mathrm{ID} \\
\text { (2000) IL (1999) IN (2000) KS (2000) KY (2000) LA (2001) MA } \\
\text { (2004) MD (2000) ME (2000) MI (2000) MN (2000) MO (2003) MS } \\
\text { (2001) MT (2001) NC (2000) ND (2001) NE (2000) NH (2001) NJ } \\
\text { (2001) NM (2001) NV (2001) NY (1999) OH (2000) OK (2000) OR } \\
\text { (2001) PA (1999) RI (2000) SC (2004) SD (2000) TN (2001) TX } \\
\text { (2001) UT (2000) VA (2000) VT (2003) WA (1996) WI (2004) WV } \\
\text { (2001) WY (2001) }\end{array}$ \\
\hline E-Waste Recycling & $\begin{array}{l}\text { CA (2003) CT (2007) HI (2008) IL (2008) IN (2009) MD (2005) } \\
\text { ME (2004) MI (2008) MN (2007) MO (2008) NC (2007) NJ (2008) } \\
\text { NY (2010) OK (2008) OR (2007) PA (2010) RI (2008) SC (2007) } \\
\text { TX (2007) UT (2011) VA (2008) VT (2009) WA (2006) WI (2009) } \\
\text { WV (2010) }\end{array}$ \\
\hline E-Cig Bans & $\begin{array}{l}\mathrm{AK}(2012) \mathrm{AL}(2013) \mathrm{AR}(2013) \mathrm{AZ}(2013) \mathrm{CA}(2010) \mathrm{CO}(2014) \\
\mathrm{CT}(2014) \mathrm{DE}(2014) \mathrm{FL}(2014) \mathrm{GA}(2014) \mathrm{HI}(2013) \mathrm{IA}(2014) \mathrm{ID} \\
\text { (2012) IL (2014) IN (2014) KS (2012) KY (2014) LA (2014) MD } \\
\text { (2012) MI (2014) MN (2010) MO (2014) MS (2013) NC (2013) NE } \\
\text { (2014) NH (2010) NJ (2009) NV (2013) NY (2013) OH (2014) OK } \\
\text { (2014) RI (2014) SC (2013) SD (2014) TN (2011) UT (2010) VA } \\
\text { (2014) VT (2014) WA (2013) WI (2011) WV (2014) WY (2013) }\end{array}$ \\
\hline
\end{tabular}


Table 9: Policy Adoption Dates for Policies without Model Legislation

\begin{tabular}{|c|c|}
\hline Policy & Adopters (Year) \\
\hline Safe Haven & $\begin{array}{l}\mathrm{AK}(2008) \mathrm{AL}(2000) \mathrm{AR}(2001) \mathrm{AZ}(2001) \mathrm{CA}(2001) \mathrm{CO}(2000) \\
\mathrm{CT}(2000) \mathrm{DE}(2001) \mathrm{FL}(2000) \mathrm{GA}(2002) \mathrm{HI}(2007) \mathrm{IA}(2001) \mathrm{ID} \\
\text { (2001) IL (2001) IN (2000) KS (2006) KY (2002) LA (2003) MA } \\
\text { (2004) MD (2000) ME (2001) MI (2000) MN (2000) MO (2002) MS } \\
\text { (2001) MT (2001) NC (2001) ND (2001) NE (2008) NH (2003) NJ } \\
\text { (2000) NM (2001) NV (2001) NY (2000) OH (2001) OK (2001) OR } \\
\text { (2001) PA (2002) RI (2001) SC (2000) SD (2001) TN (2001) TX } \\
\text { (1999) UT (2001) VA (2003) VT (2005) WA (2002) WI (2001) WV } \\
\text { (2000) WY (2003) }\end{array}$ \\
\hline Three Strikes & $\begin{array}{l}\text { AR (1995) CA (1994) CO (1994) CT (1994) FL (1995) GA (1994) } \\
\text { IN (1994) KS (1994) LA (1994) MD (1994) MT (1995) NC (1994) } \\
\text { ND (1995) NM (1994) NV (1995) PA (1995) SC (1995) TN (1995) } \\
\text { UT (1995) VA (1995) VT (1995) WA (1993) WI (1994) }\end{array}$ \\
\hline I'm Sorry & $\begin{array}{l}\text { AK (2014) AZ (2005) CA (2000) CO (2003) CT (2005) DE (2006) } \\
\text { FL (2001) GA (2005) HI (2007) IA (2006) ID (2006) IL (2005) IN } \\
\text { (2006) LA (2006) MA (1986) MD (2005) ME (2005) MI (2011) MO } \\
\text { (2005) MT (2005) NC (2004) ND (2007) NE (2007) NH (2006) OH } \\
\text { (2004) OK (2004) OR (2003) PA (2013) SC (2006) SD (2005) TX } \\
\text { (1999) UT (2006) VA (2005) VT (2005) WA (2002) WI (2014) WV } \\
\text { (2005) WY (2004) }\end{array}$ \\
\hline $\begin{array}{l}\text { Guaranteed Insurance } \\
\text { Renewal }\end{array}$ & $\begin{array}{l}\text { AZ (1997) CA (1992) CO (1996) CT (1997) DE (1997) FL (1997) } \\
\text { GA (1995) HI (1997) IA (1995) ID (1994) IL (1997) IN (1998) KS } \\
\text { (1997) KY (1994) LA (1993) MD (1993) ME (1993) MI (1996) MN } \\
\text { (1992) MS (1997) MT (1997) NC (1997) ND (1995) NE (1997) NH } \\
\text { (1992) NJ (1992) NM (1998) NV (1997) NY (1992) OH (1997) OR } \\
\text { (1995) PA (1997) RI (1995) SC (1997) SD (1997) TN (1997) TX } \\
\text { (1997) UT (1995) VA (1996) VT (1997) WA (1993) WI (1997) WV } \\
\text { (1997) WY (1995) }\end{array}$ \\
\hline School Vouchers & $\begin{array}{l}\mathrm{AZ}(2011) \mathrm{FL}(2001) \mathrm{GA}(2007) \mathrm{IN}(2011) \mathrm{LA}(2008) \mathrm{MS}(2012) \\
\mathrm{NC}(2013) \mathrm{OH}(2005) \mathrm{UT}(2005) \mathrm{OK}(2010) \mathrm{WI}(1990)\end{array}$ \\
\hline $\begin{array}{l}L G B T \quad \text { Employment } \\
\text { Nondiscrimination }\end{array}$ & $\begin{array}{l}\text { CA (1991) CO (2007) CT (1991) DE (2009) HI (1991) IA (2007) } \\
\text { IL (2005) MA (1989) MD (2001) ME (2005) MN (1993) NH (1998) } \\
\text { NJ (1992) NM (2003) NV (1999) NY (2002) OR (2007) RI (1995) } \\
\text { VT (1992) WA (2006) WI (1982) }\end{array}$ \\
\hline
\end{tabular}

